\title{
Selenium and Other Trace Elements in the Etiology of Parkinson's Disease: A Systematic Review and Meta-Analysis of Case-Control Studies
}

\author{
Giorgia Adani $^{a}$ Tommaso Filippini ${ }^{a}$ Bernhard Michalke ${ }^{b}$ Marco Vinceti ${ }^{a}$ c \\ a Environmental, Genetic and Nutritional Epidemiology Research Center, Department of Biomedical, Metabolic and \\ Neural Sciences, Section of Public Health, University of Modena and Reggio Emilia, Modena, Italy; ${ }^{\mathrm{b}}$ Research Unit \\ Analytical BioGeoChemistry, German Research Center for Environmental Health, Helmholtz Zentrum Muenchen, \\ Neuherberg, Germany; ${ }^{C}$ Department of Epidemiology, Boston University School of Public Health, Boston, MA, USA
}

\section{Keywords}

Parkinson's disease $\cdot$ Selenium $\cdot$ Copper $\cdot$ Iron $\cdot$ Zinc .

Etiology

\begin{abstract}
Background: Parkinson's disease (PD) is the most common neurodegenerative disease after Alzheimer's dementia. Whereas the exact etiology of PD remains unknown, risk of developing PD seems to be related to a combination of genetic and environmental factors. This also includes abnormal exposure to trace elements of nutritional and toxicological interest. Objectives: In this systematic review and metaanalysis, we summarized the results of case-control studies comparing levels of selenium, copper, iron, and zinc in PD patients and controls in either blood (whole blood, serum/ plasma) or cerebrospinal fluid (CSF). Methods: We performed a systematic PubMed search selecting studies reporting trace element levels in different specimens of patients and controls. We performed a meta-analysis using a random-effect model to compute the weighted mean differences (WMD) and corresponding $95 \% \mathrm{Cl}$ of selenium, copper, iron, and zinc levels in the blood or CSF of patients and their matched controls. Results: We retrieved 56 papers reporting data for selenium (cases/controls: 588/721), copper
\end{abstract}

$(2,190 / 2,522)$, iron $(2,956 / 3,469)$, and zinc $(1,798 / 1,913)$ contents in CSF and blood. Cases showed considerably higher levels of selenium in CSF compared with controls $(+51.6 \%$; WMD 5.49; $95 \% \mathrm{Cl} 2.82$ to 8.15 ), while levels in serum were similar (-0.2\%; WMD $-0.22 ; 95 \% \mathrm{Cl}-8.05$ to 7.62$)$. For copper, cases showed slightly higher levels in CSF and slightly lower concentrations in serum $(+4.5 \%$; WMD $1.87 ; 95 \% \mathrm{Cl}-3.59$ to 7.33, and $-4.5 \%$; WMD $-42.79 ; 95 \% \mathrm{Cl}-134.35$ to 48.76 , respectively). A slight increase was also found for CSF iron levels (+9.5\%; WMD 9.92; 1.23 to 18.61 ), while levels were decreased in serum/plasma $(-5.7 \%$; WMD $-58.19 ; 95 \%$ $\mathrm{Cl}-106.49$ to -9.89$)$ and whole blood (-10.8\%; WMD -95.69; $95 \% \mathrm{Cl}-157.73$ to -33.65$)$. Conversely, for zinc cases exhibited lower levels both in CSF $(-10.8 \%$; WMD $-7.34 ; 95 \% \mathrm{CI}$ -14.82 to 0.14$)$ and serum/plasma $(-7.5 \%$; WMD $-79.93 ; 95 \%$ $\mathrm{Cl}-143.80$ to -16.06$)$. A longer duration of the disease tends to be associated with overall lower trace element levels in either CSF or blood. Conclusions: Due to the study findings and the greater relevance of the CSF compartment compared with the circulating peripheral ones, this meta-analysis suggests that overexposure in the central nervous system to selenium, and possibly to copper and iron, may be a risk factor of the disease, while zinc might have a protective effect.

\section{KARGER}

(C) 2019 S. Karger AG, Basel

E-Mail karger@karger.com

www.karger.com/ned
Marco Vinceti

Department of Biomedical, Metabolic and Neural Sciences

University of Modena and Reggio Emilia

via Campi IT-287, Modena (Italy)

E-Mail marco.vinceti@unimore.it 


\section{Introduction}

Parkinson's disease (PD) is a neurodegenerative disorder with predominantly motor manifestations such as akinesia and bradykinesia, tremor, muscle stiffness, and postural instability [1]. Nonmotor symptoms also exist, including anxiety, depression, and constipation. These clinical manifestations are the result of dopaminergic neuron death. Dopaminergic neurons are cells located in the pars compacta of substantia nigra, a mesencephalic section entrusted with dopamine synthesis and release. PD is recognized as the most common neurological disorder after Alzheimer's dementia [2]. In industrialized countries, the prevalence is approximately $0.3 \%$ in the general population, with increasing value in the elderly, that is, $1.0 \%$ in people aged $\geq 60$ years, and $3.0 \%$ in those aged $\geq 80$ years $[1,3]$. Overall, PD annual incidence ranges from 8 to 18 per 100,000 inhabitants, with a male-to-female ratio around 1.5. Since ageing is the most important risk factor, its prevalence and burden are expected to increase over the next decades $[1,4,5]$.

Although the exact cause of PD remains unknown, it seems to be related to interrelation of genetic and environmental factors [6, 7]. For instance, caffeine [3] and in a more controversial way smoking $[8,9]$ have been suggested as possible protective factors, while exposure to pesticides, especially rotenone and paraquat, derivatives of 1-methyl4-phenyl-1,2,3,6-tetrahydropyridine, traumatic brain injuries, and occupational exposure to pesticides and heavy metals appear to be detrimental risk factors for the disease [3]. Additionally, alterations in trace element homeostasis have been suggested to play a role in the etiology of PDrelated neurodegeneration. In particular, abnormal levels of some heavy metals and metalloids, such as selenium, copper, iron, and zinc, can adversely affect the nervous system through the induction of reactive oxygen species production [10-12]. However, the role of selenium and other trace elements is still controversial, and the recent available reviews on the topic are either missing or out-of-date.

We carried out an updated systematic review and meta-analysis, in which we summarized the results of casecontrol studies reporting levels of selenium, copper, iron, and zinc in the blood and cerebrospinal fluid (CSF) of PD patients compared with controls.

\section{Methods}

Literature Search

We performed a systematic search in the PubMed/Medline database using the MeSH Terms "PD" and "trace elements" (including individual elements) through July 4, 2019 (Box 1 of Fig. 1).
Inclusion criteria were studies carried out in humans, observational design, and reporting levels of selenium, copper, iron, and zinc in either whole blood, serum, plasma, or CSF. Exclusion criteria were studies not carried out in humans, those not having an observational design or not reporting trace element contents, those including cases of Parkinsonism, autoptic studies, studies evaluating levels of elements other than selenium, copper, iron, and zinc, and those carried out in tissues rather than whole blood, serum, plasma or CSF.

\section{Data Extraction}

For each study, we extracted the year of publication, country of region and sample size, data about demographic characteristics of cases and controls (i.e., age and sex), and, for cases, disease duration and severity score (Hoehn and Yahr stage of disease [13]). For each study population, we extracted the trace element levels into a database in different specimens (whole blood, serum, plasma, and $\mathrm{CSF}$ ), as mean $\pm \mathrm{SD}$ in $\mu \mathrm{g} / \mathrm{L}$ or median and interquartile range, when these were the only available data [14-17]. When only means or medians with their range were reported, we calculated SD = range/4. When the interquartile range was reported, we computed $\mathrm{SD}$ as $\left(\mathrm{Q}_{3}-\mathrm{Q}_{1}\right) / 1.35$ and, when only $95 \%$ CI was reported, we cal-

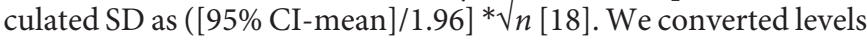
reported in $\mu \mathrm{mol} / \mathrm{L}$ into molar mass. When there were $>1$ group of cases or controls [19-22], we computed a combined weighted mean and SD (online suppl. Table S1; for all online suppl. material, see www.karger.com/doi/10.1159/000502357 for detailed methods).

For 1 study [23], we asked the authors to kindly provide additional data not reported in the paper. Moreover, for a study in which 2 sets of cases and controls were reported [24], the few patients with longer-duration PD $(6.0 \pm 4.6$ years $)$ and the controls with the lowest age were not included in our analysis, to make cases and controls comparable for age (60.8 and 61.2 years, respectively). Finally, serum selenium levels in 1 study appeared to be entirely implausible due to extremely low values in patients, as it was the case with serum iron levels in both cases and controls in 2 studies. Thus, we excluded these studies from further analysis about serum levels [25-27].

\section{Data Analysis}

We performed a meta-analysis of the mean differences of trace element levels in cases and controls on the basis of data extracted from the abovementioned studies, using a random-effect model to account for possible study heterogeneity (assessed with the $I^{2}$ statistic). We computed a weighted mean difference (WMD) with corresponding 95\% CI of serum/plasma, whole blood, and CSF levels of selenium, copper, iron, and zinc. We also assessed publication bias by using funnel plots according to each biomarker of exposure. We carried out all statistical analyses with the Stata-15.1 package, by using the "metan" routine (Stata Corp., TX 2019).

\section{Results}

We originally identified a total number of 555 articles through PubMed/Medline. From these, we excluded 475 studies which, after title and abstract screening, 
Fig. 1. Flow chart summarizing study identification and selection and reporting details of PubMed search strategy, up through July 4, 2019. PD, Parkinson's disease; CSF, cerebrospinal fluid.

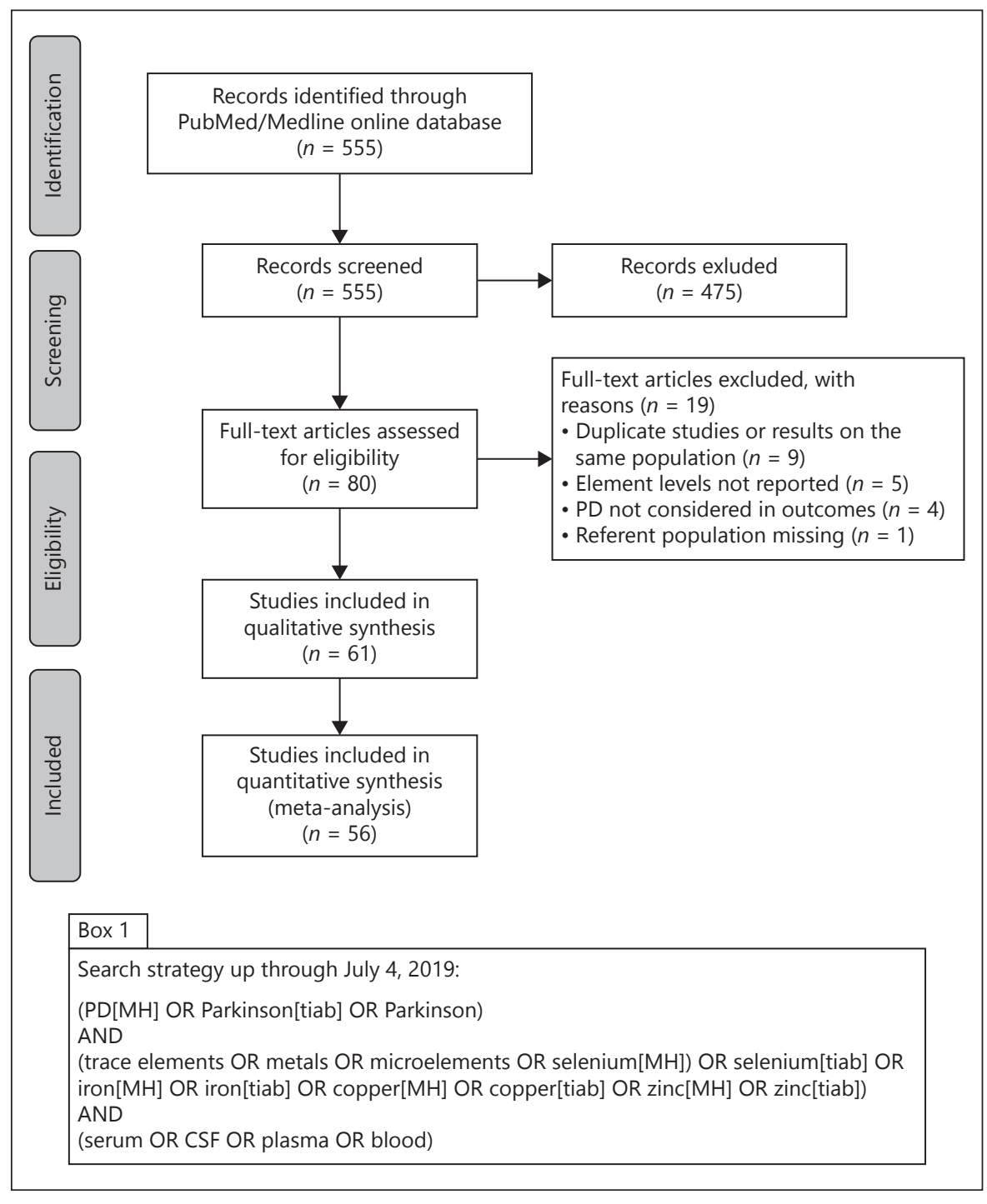

were not relevant (Fig. 1). After a full-text evaluation of the remaining papers, we excluded 19 more papers for the reasons reported in Figure 1. We also excluded repeated or overlapping publications, by removing the earliest or the most incomplete ones [28-36]. We eventually selected 61 case-control studies for the present review (Table 1). These studies reported mean trace element levels in specimens such as whole blood $(n=2)$, plasma and serum $(n=50)$, red blood cells $(n=2)$, hair $(n=1)$, and CSF $(n=14)$. Of these, 56 studies could be included in our meta-analysis, while the remaining 5 were only used in narrative synthesis. For selenium, we retrieved data on 588 cases and 721 controls (based on 3 studies on CSF and 11 on serum/plasma); for copper, 2,190 cases and 2,522 controls (10 studies on CSF and 28 on serum/plasma); for iron, 2,956 cases and 3,469 controls (12 studies on CSF, 32 on serum/plasma, and 2 on whole blood); for zinc, 1,798 cases and 1,913 controls (7 studies on CSF and 21 on serum/plasma). Overall, these studies were published between 1967and 2019 and carried out in different countries: $43 \%$ in Europe $(n=$ 24, of which 9 in Italy and 5 in Spain), 37\% in Asia ( $n=$ 21 , of which 7 in India and 7 in China), and 20\% in America $(n=11,7$ in the United States and 5 in South America).

Most studies reported age and sex of study subjects, while disease duration was available only in 29 of the 61 studies considered in the descriptive analysis reported in Table 1 and disease severity in 19 studies. Two studies assessed serum iron levels [15] and copper levels [37] only in men, while the remaining ones evaluated trace elements in both sexes. 


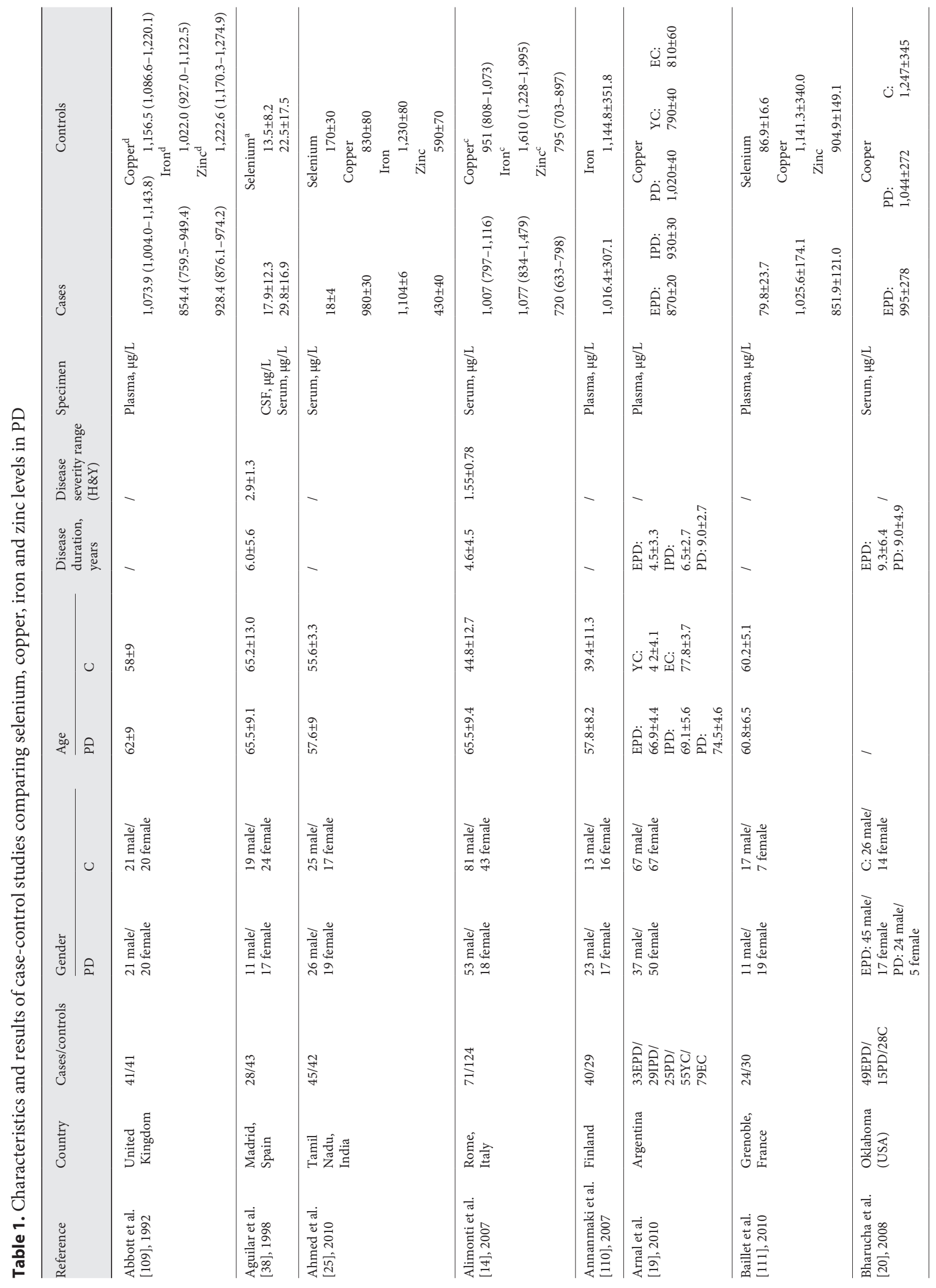




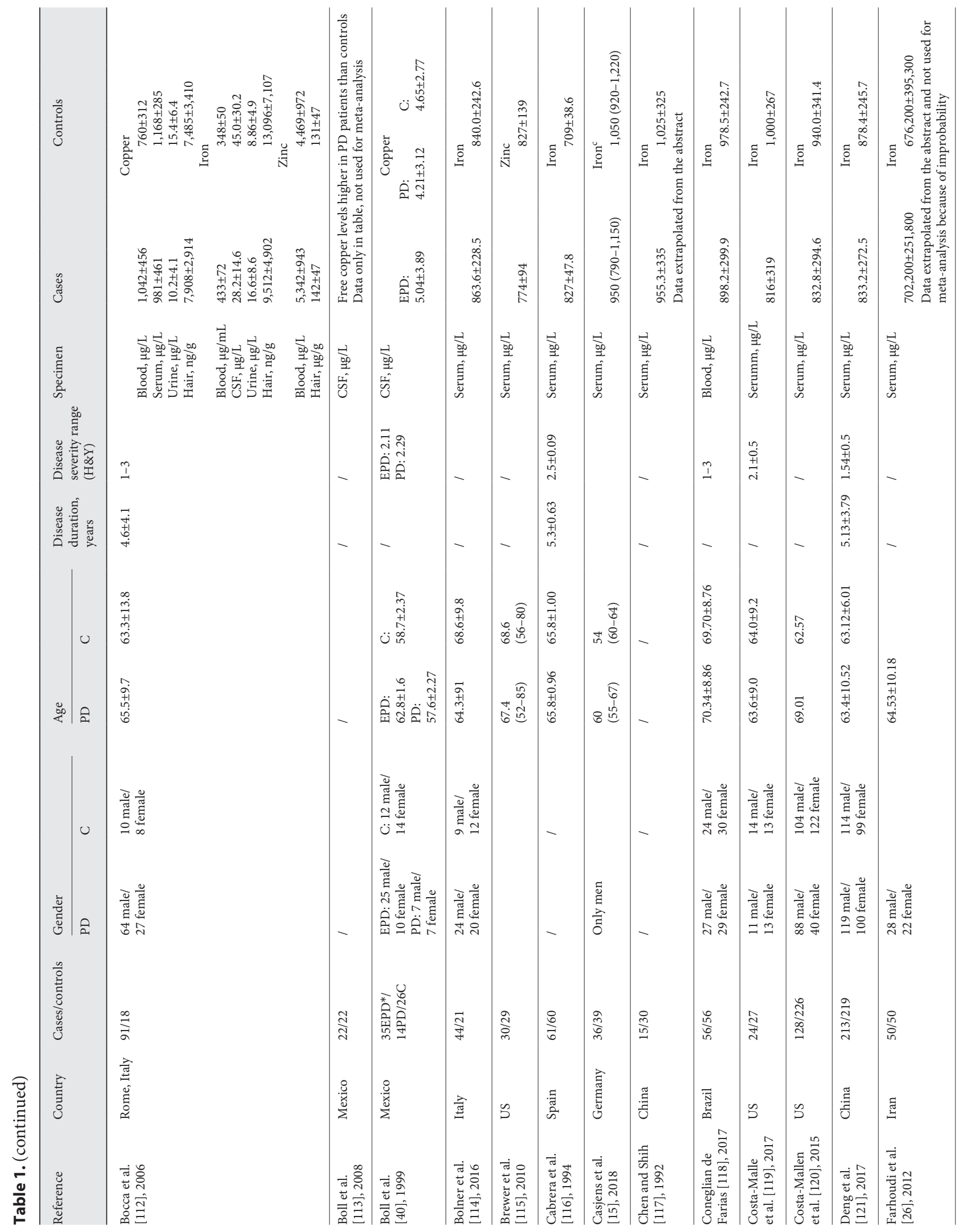




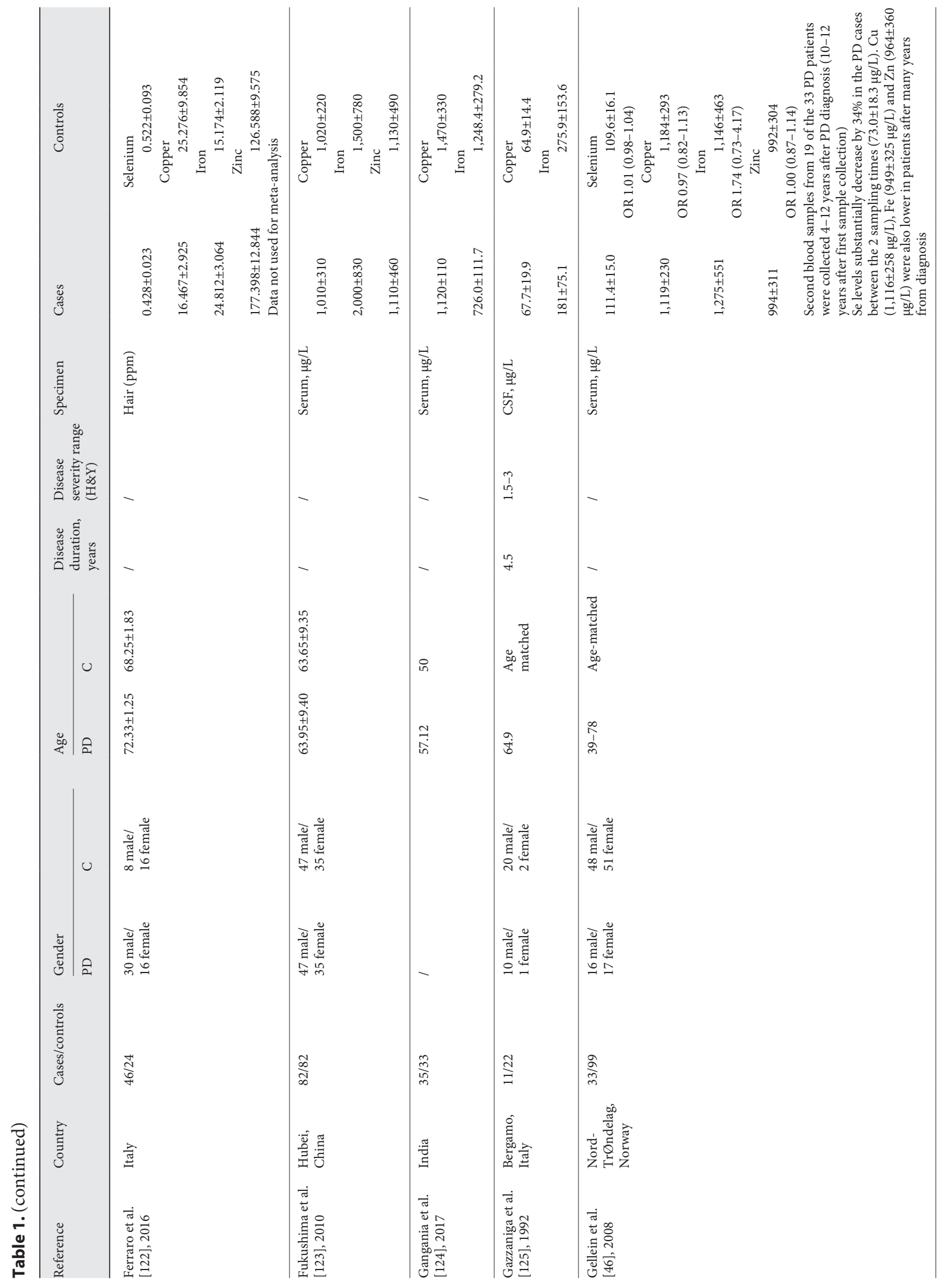




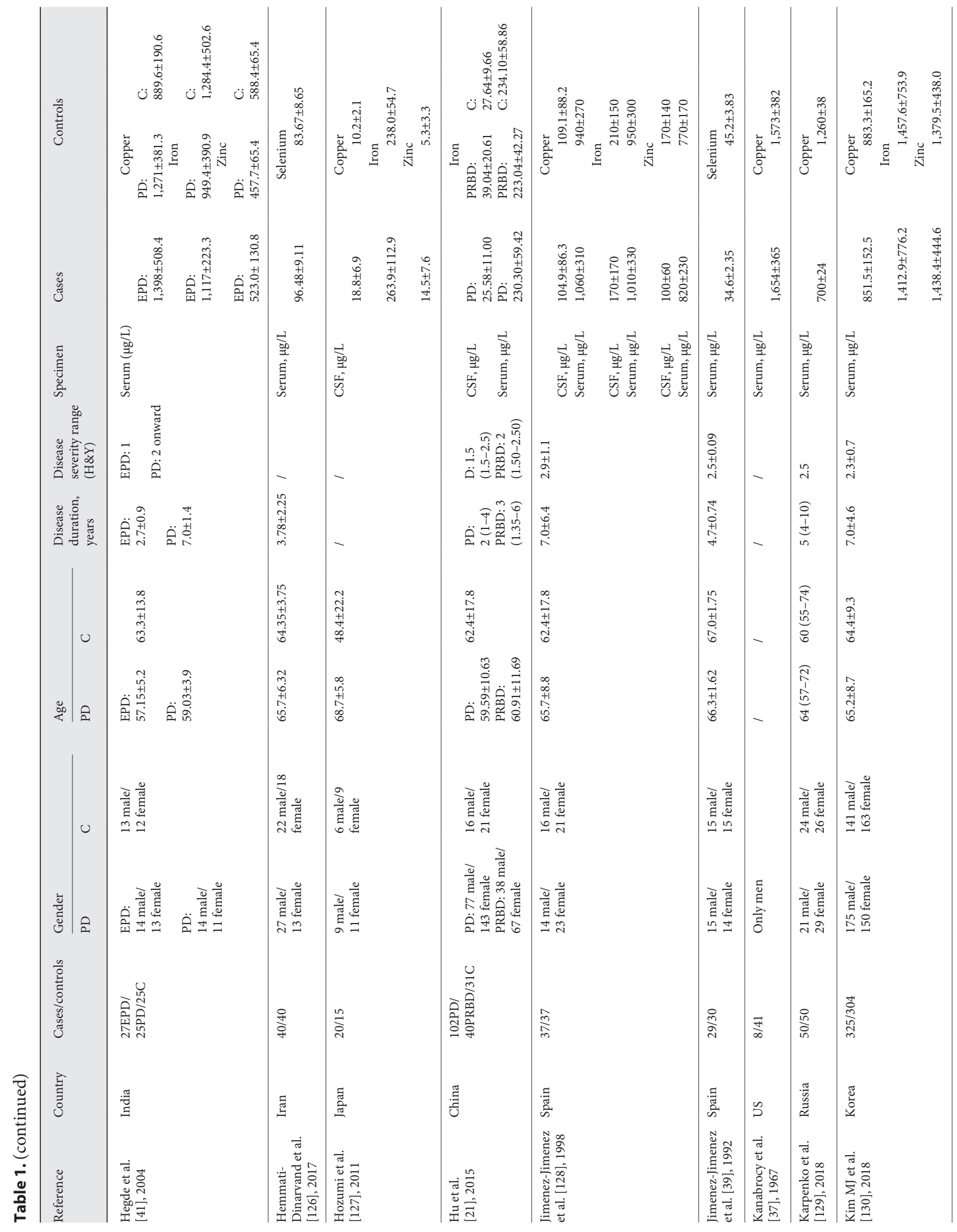




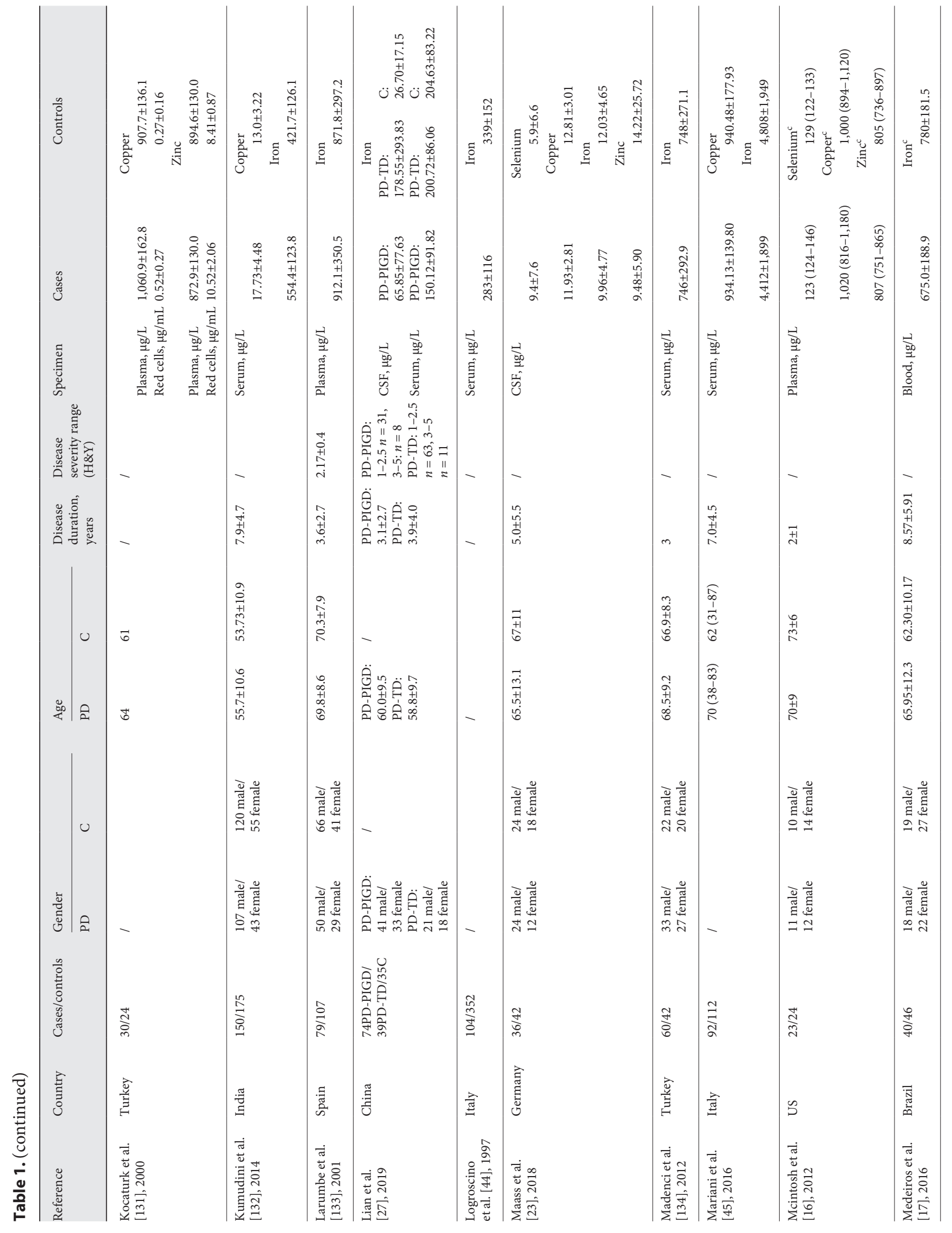




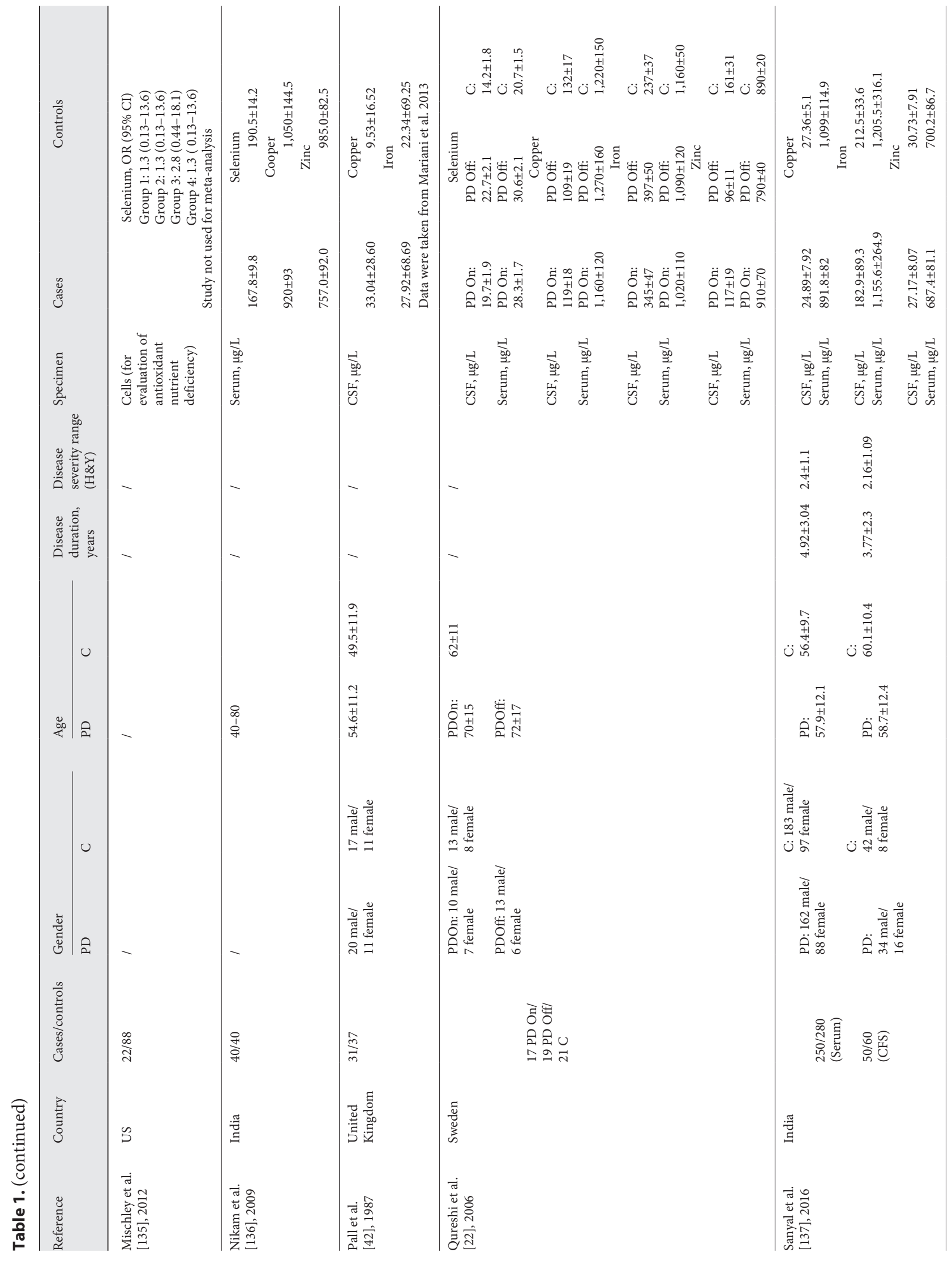




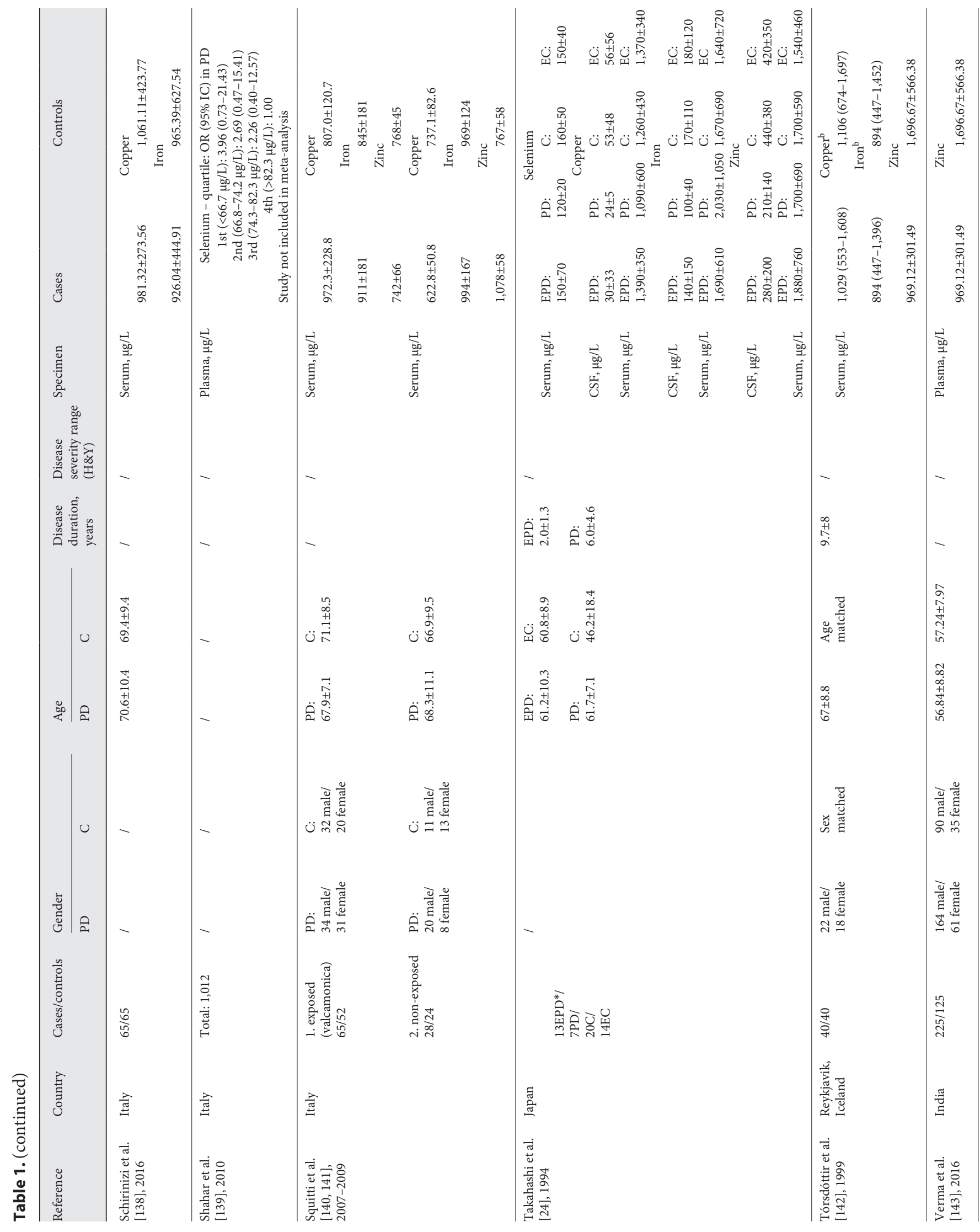




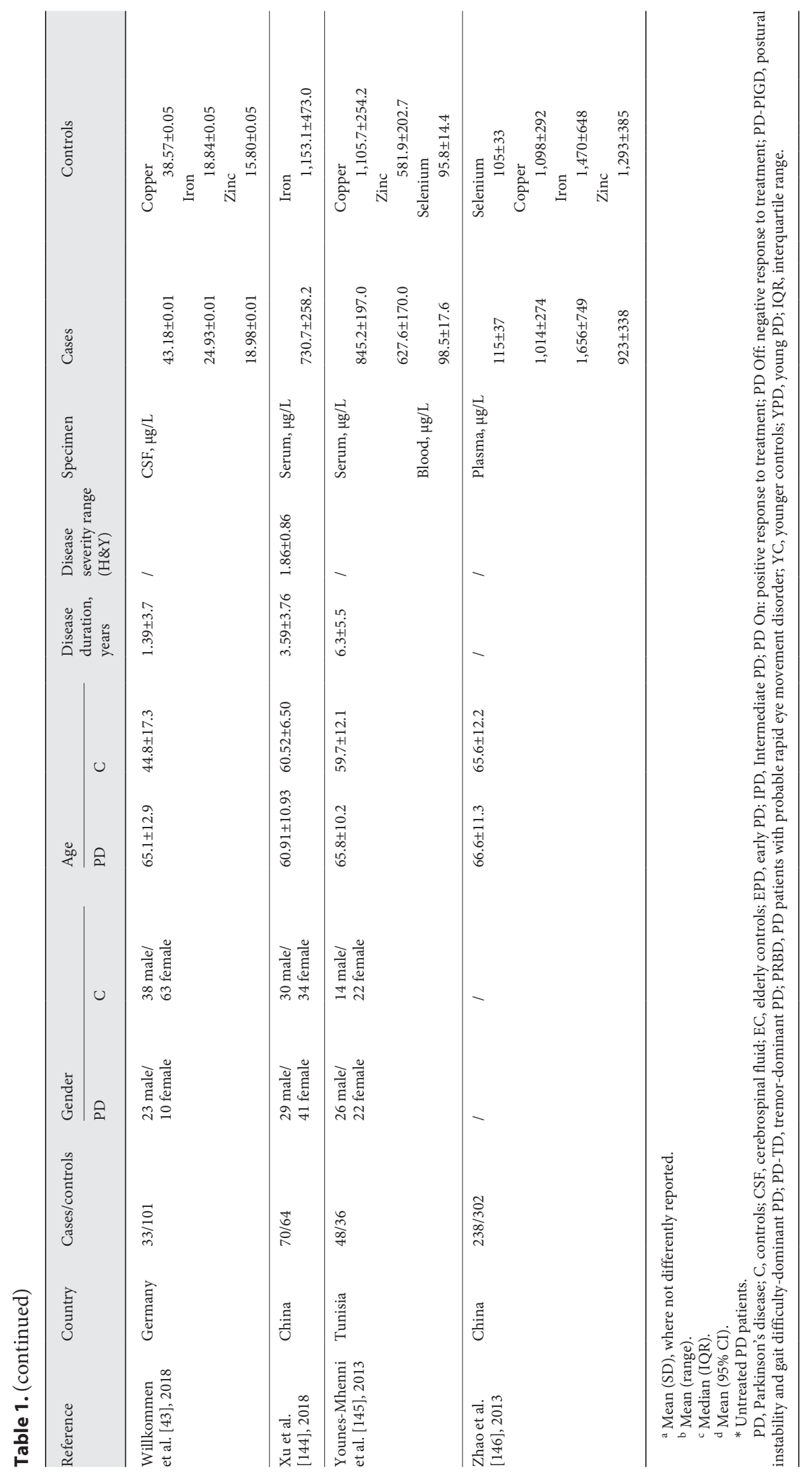




\begin{tabular}{|c|c|c|c|c|c|c|c|}
\hline Reference & & & & WMD $(95 \% \mathrm{Cl})$ & $\begin{array}{l}\% \\
\text { weight }\end{array}$ & $\begin{array}{l}\text { Levels in } \\
\text { cases }\end{array}$ & $\begin{array}{l}\text { Levels in } \\
\text { controls }\end{array}$ \\
\hline \multicolumn{8}{|l|}{ Serum/plasma } \\
\hline Takahashi, 2-1994 & & & & $0.00(-43.44,43.44)$ & 2.48 & 150 & 150 \\
\hline Jimenez-Jimenez, 1995 & & $\rightarrow-$ & & $-10.60(-12.22,-8.98)$ & 10.36 & 34.6 & 45.2 \\
\hline Aguilar, 1998 & & & $\rightarrow$ & $7.30(-0.86,15.46)$ & 9.35 & 29.8 & 22.5 \\
\hline Qureshi, 2006 & & & $\leftarrow$ & $8.81(7.84,9.78)$ & 10.39 & 29.51 & 20.7 \\
\hline Gellein, 2008 & & & $\rightarrow$ & $1.80(-4.22,7.82)$ & 9.80 & 111.4 & 109.6 \\
\hline Nikam, 2009 & + & & & $-22.70(-28.05,-17.35)$ & 9.92 & 167.8 & 190.5 \\
\hline Baillet, 2010 & & & & $-7.10(-18.29,4.09)$ & 8.58 & 79.8 & 86.9 \\
\hline Mcintosh, 2012 & & 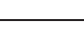 & - & $-6.00(-13.42,1.42)$ & 9.52 & 123 & 129 \\
\hline Younes-Mhenni, 2013 & & & $\rightarrow$ & $2.70(-4.15,9.55)$ & 9.64 & 98.5 & 95.8 \\
\hline Zhao, 2013 & & & $\longrightarrow$ & $10.00(4.00,16.00)$ & 9.81 & 115 & 105 \\
\hline Hemmati-Dinavard, 2017 & & & $\longrightarrow$ & $12.81(8.92,16.70)$ & 10.15 & 96.48 & 83.67 \\
\hline Subtotal $\left(R^{2}=98.1 \%\right)$ & & & $=$ & $-0.22(-8.05,7.62)$ & 100.00 & & \\
\hline \multicolumn{8}{|l|}{ CSF } \\
\hline Aguilar, 1998 & & & $\longrightarrow$ & $4.40(-0.77,9.57)$ & 17.98 & 17.9 & 13.5 \\
\hline Qureshi, 2006 & & & & $7.08(5.96,8.20)$ & 50.94 & 21.28 & 14.2 \\
\hline Maass, Michalke, 2018 & & & $\rightarrow$ & $3.50(0.31,6.69)$ & 31.08 & 9.4 & 5.9 \\
\hline \multicolumn{3}{|l|}{ Subtotal $(R=60.3 \%)$} & & $5.49(2.82,8.15)$ & 100.00 & & \\
\hline-30 & -20 & -10 & 10 & 20 & & & \\
\hline
\end{tabular}

Fig. 2. Mean difference in individual studies and summary WMD of selenium levels $(\mu \mathrm{g} / \mathrm{L})$ in serum/plasma and in CSF in patients with PD compared with controls. WMD, weighted mean difference; CSF, cerebrospinal fluid.

Table 2. WMD of the trace element concentrations (in $\mu \mathrm{g} / \mathrm{L}$ ) between patients with PD and controls, with corresponding $95 \% \mathrm{CI}$ and percentage difference in patients (\%)

\begin{tabular}{|c|c|c|c|c|c|}
\hline Element & Matrix & Studies, $n$ & WMD & $95 \% \mathrm{CI}$ & Difference, \% \\
\hline \multirow[t]{3}{*}{ Selenium } & CSF & 3 & 5.49 & 2.82 to 8.15 & +51.6 \\
\hline & Serum/plasma & 11 & -0.22 & -8.05 to 7.62 & -0.2 \\
\hline & Whole blood & / & / & / & / \\
\hline \multirow[t]{3}{*}{ Copper } & CSF & 10 & 1.87 & -3.59 to 7.33 & +4.5 \\
\hline & Serum/plasma & 28 & -42.79 & -134.35 to 48.76 & -4.5 \\
\hline & Whole blood & I & / & / & I \\
\hline \multirow[t]{3}{*}{ Iron } & CSF & 12 & 9.92 & 1.23 to 18.61 & +9.5 \\
\hline & Serum/plasma & 32 & -58.19 & -106.49 to -9.89 & -5.7 \\
\hline & Whole blood & 2 & -95.69 & -157.73 to -33.65 & -10.8 \\
\hline \multirow[t]{3}{*}{ Zinc } & CSF & 7 & -7.34 & -14.82 to 0.14 & -10.8 \\
\hline & Serum/plasma & 21 & -79.93 & -143.80 to -16.06 & -7.5 \\
\hline & Whole blood & / & I & / & 1 \\
\hline
\end{tabular}

WMD, weighted mean difference; PD, Parkinson's disease; CSF, cerebrospinal fluid.

\section{Selenium}

We could analyze data from 12 studies (Table 2). For serum/plasma selenium concentrations, there was almost no difference between the weighted average levels in cases and controls (WMD $-0.22 \mu \mathrm{g} / \mathrm{L}, 95 \% \mathrm{CI}-8.05$ to 7.62), while selenium concentrations in the CSF were considerably higher in patients $(+51.6 \%)$, based on 3 studies (WMD +5.49 $\mu \mathrm{g} / \mathrm{L}, 95 \%$ CI 2.82-8.15). There was little evidence of publication bias (online suppl. Fig. S1). Heterogeneity for serum/plasma selenium levels was very high (98.1\%), while for studies based on CSF levels it amounted to $60.3 \%$ (Fig. 2). Average selenium levels across the studies were substantially similar, apart from 2 old Spanish studies [38, 39] and a more recent study [22], showing much lower concentrations. 


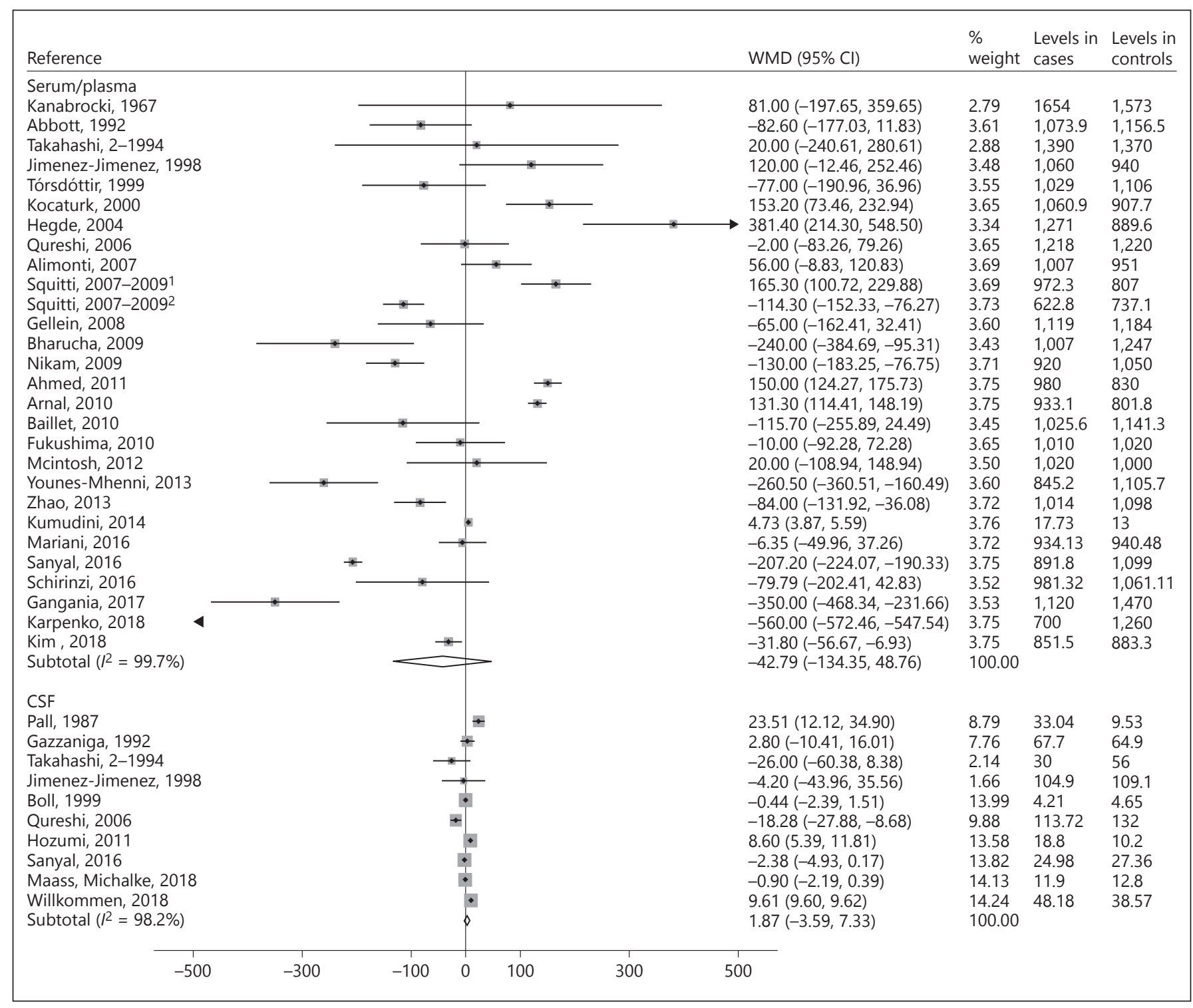

Fig. 3. Mean difference in individual studies and summary WMD of copper levels $(\mu \mathrm{g} / \mathrm{L})$ in serum/plasma and in CSF in patients with PD compared with controls. WMD, weighted mean difference; CSF, cerebrospinal fluid.

\section{Copper}

As shown in Table 2, average CSF copper concentrations were slightly higher $(+4.5 \%)$ in patients than in controls (WMD +1.87 , 95\% CI -3.59 to 7.33 ), whereas se$\mathrm{rum} /$ plasma copper levels were slightly lower in patients ( $-4.5 \%$, WMD $-42.79,95 \%$ CI -134.35 to 48.76 - Fig. 3 ). Some slight evidence of publication bias emerged, as shown in online Supplementary Figure S1. Heterogeneity was very high in both analyses $\left(I^{2}=99.7\right.$ and $96.5 \%$ for serum/plasma and CSF levels, respectively, Fig. 3). Average copper concentrations measured in CSF varied considerably across studies, while copper mean levels in se- rum/plasma were considerably more similar. Results did not substantially change when we restricted the analysis to earlier PD cases only, as reported in 2 studies $[40,41]$ with serum/plasma WMD -39.54 (95\% CI -131.22 to 52.14 and CSF WMD 2.01, 95\% CI -3.34 to 7.35 ; online suppl. Fig. S2).

\section{Iron}

Based on 33 studies, iron levels in plasma or serum were slightly lower in patients (-5.7\%; WMD $-58.19 \mu \mathrm{g} / \mathrm{L}, 95 \%$ CI -106.49 to -9.89 ), and this was also true for whole blood concentrations as reported in 2 studies $(-10.8 \%$; 


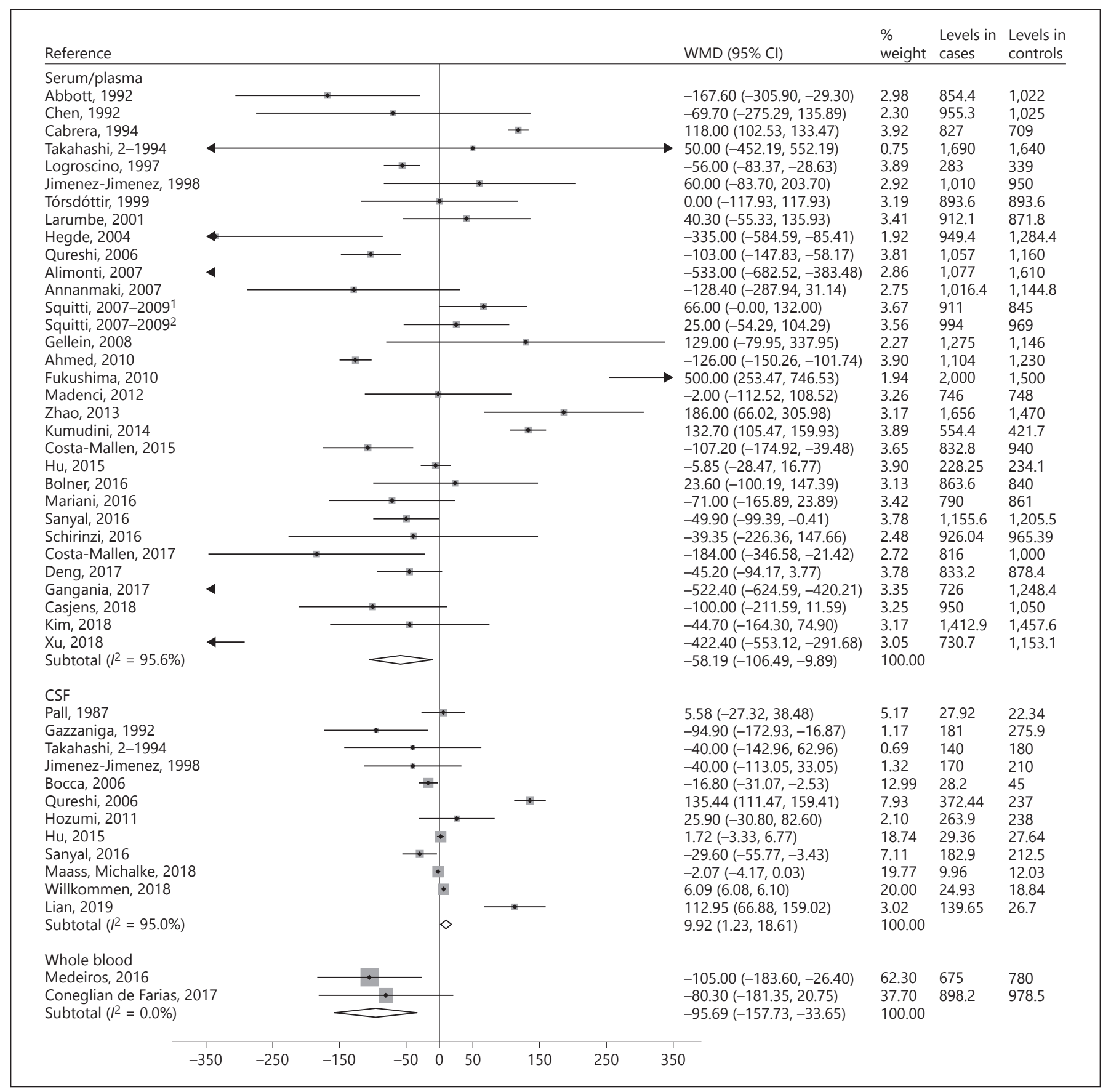

Fig. 4. Mean difference in individual studies and summary WMD of iron levels $(\mu \mathrm{g} / \mathrm{L})$ in serum/plasma, whole blood, and in CSF in patients with PD compared with controls. WMD, weighted mean difference; CSF, cerebrospinal fluid.

WMD -95.69, 95\% CI -157.73 to -33.65 - Table 2 and Fig. 4). Conversely, CSF iron content was slightly higher $(+9.5 \%)$ in patients compared with controls (WMD 9.92 $\mu \mathrm{g} / \mathrm{L}, 95 \%$ CI 1.23-18.61). By repeating the analysis restricted to patients with shorter duration PD in 1 study
[41], results changed little (serum/plasma WMD -55.31, $95 \%$ CI -103.38 to -7.24 ; online suppl. Fig. S3). High heterogeneity characterized both studies based on serum or plasma levels $\left(I^{2}=95.6 \%\right)$ and those reporting CSF levels $\left(I^{2}=95.0 \%\right)$, but not those analyzing whole blood concen- 


\begin{tabular}{|c|c|c|c|c|c|c|c|}
\hline \multicolumn{4}{|l|}{ Reference } & WMD $(95 \% \mathrm{Cl})$ & $\begin{array}{l}\% \\
\text { weight }\end{array}$ & $\begin{array}{l}\text { Levels in } \\
\text { cases }\end{array}$ & $\begin{array}{l}\text { Levels in } \\
\text { controls }\end{array}$ \\
\hline \multicolumn{8}{|l|}{ Serum/plasma } \\
\hline \multicolumn{8}{|c|}{$-294.20(-363.72,-224.68)$} \\
\hline \multicolumn{8}{|c|}{$340.00(-138.27,818.27)$} \\
\hline \multirow{2}{*}{\multicolumn{2}{|c|}{$\begin{array}{l}\text { Jimenez-Jimenez, } 1998 \\
\text { Kocaturk, } 2000\end{array}$}} & & $\longrightarrow$ & $50.00(-42.16,142.16)$ & 4.72 & 820 & 770 \\
\hline & & $\longrightarrow$ & & $-21.70(-91.48,48.08)$ & 4.92 & 872.9 & 894.6 \\
\hline \multicolumn{2}{|l|}{ Hegde, 2004} & - & & $-130.70(-166.96,-94.44)$ & 5.14 & 457.7 & 588.4 \\
\hline \multicolumn{2}{|l|}{ Qureshi, 2006} & $\longrightarrow$ & & $-43.33(-71.48,-15.18)$ & 5.18 & 846.67 & 890 \\
\hline \multicolumn{2}{|l|}{ Alimonti, 2007} & $\longrightarrow$ & & $-75.00(-113.05,-36.95)$ & 5.14 & 720 & 795 \\
\hline \multicolumn{2}{|l|}{ Squitti, 2007-20091 } & $\longrightarrow$ & & $-26.00(-46.18,-5.82)$ & 5.20 & 742 & 768 \\
\hline \multicolumn{2}{|l|}{ Squitti, 2007-2009² } & & & - $311.00(279.38,342.62)$ & 5.17 & 1,078 & 767 \\
\hline \multicolumn{2}{|l|}{ Gellein, 2008} & & & $2.00(-119.84,123.84)$ & 4.40 & 994 & 992 \\
\hline \multicolumn{2}{|l|}{ Nikam, 2009} & & & $-228.00(-266.29,-189.71)$ & 5.14 & 757 & 985 \\
\hline \multicolumn{2}{|l|}{ Ahmed, 2010} & & & $-160.00(-184.18,-135.82)$ & 5.19 & 430 & 590 \\
\hline \multicolumn{2}{|l|}{ Baillet, 2010} & $\rightarrow$ & — & $-53.00(-125.04,19.04)$ & 4.91 & 851.9 & 904.9 \\
\hline \multicolumn{2}{|l|}{ Brewer, 2010} & 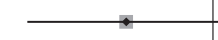 & & $-53.00(-113.75,7.75)$ & 5.00 & 774 & 827 \\
\hline \multicolumn{2}{|l|}{ Fukushima, 2010} & $\longrightarrow$ & & $-20.00(-165.47,125.47)$ & 4.12 & 1,110 & 1,130 \\
\hline \multicolumn{2}{|l|}{ Mcintosh, 2012} & & & $2.00(-56.89,60.89)$ & 5.01 & 807 & 805 \\
\hline \multicolumn{2}{|l|}{ Younes-Mhenni, 2013} & & $\longrightarrow$ & $45.70(-36.14,127.54)$ & 4.82 & 627.6 & 581.9 \\
\hline \multicolumn{2}{|l|}{ Zhao, 2013} & & & $-370.00(-431.07,-308.93)$ & 4.99 & 923 & 1,293 \\
\hline \multicolumn{2}{|l|}{ Verma, 2016} & & & $-727.55(-834.37,-620.73)$ & 4.56 & 969.12 & $1,696.67$ \\
\hline \multicolumn{2}{|l|}{ Sanyal, 2016} & $\rightarrow-1$ & & $-12.80(-27.09,1.49)$ & 5.22 & 687.4 & 700.2 \\
\hline \multicolumn{2}{|l|}{ Kim, 2018} & & & $58.90(-10.10,127.90)$ & 4.93 & $1,438.4$ & $1,379.5$ \\
\hline \multicolumn{2}{|l|}{ Subtotal $\left(R^{2}=98.1 \%\right)$} & $\longrightarrow$ & & $-79.93(-143.80,-16.06)$ & 100.00 & & \\
\hline \multicolumn{8}{|l|}{ CSF } \\
\hline & & & $-140.00(-353.15,73.15)$ & 0.12 & 280 & 420 \\
\hline \multirow{2}{*}{\multicolumn{2}{|c|}{$\begin{array}{l}\text { Jimenez-Jimenez, } 1998 \\
\text { Qureshi, } 2006\end{array}$}} & $\rightarrow$ & & $-70.00(-119.08,-20.92)$ & 2.11 & 100 & 170 \\
\hline & & $\rightarrow$ & & $-55.08(-69.66,-40.50)$ & 12.31 & 105.92 & 161 \\
\hline \multicolumn{2}{|l|}{ Hozumi, 2011} & & + & $9.20(5.47,12.93)$ & 21.84 & 14.5 & 5.3 \\
\hline \multicolumn{2}{|l|}{ Sanyal, 2016} & ! & & $-3.56(-6.56,-0.56)$ & 22.27 & 27.17 & 30.73 \\
\hline Maass, Michalke, 2018 & & $\Rightarrow$ & & $-4.74(-12.75,3.27)$ & 18.26 & 9.48 & 14.22 \\
\hline Willkommen, 2018 & & i & - & $3.18(3.17,3.19)$ & 23.09 & 18.98 & 15.8 \\
\hline Subtotal $\left(R^{2}=94.3 \%\right)$ & & $\Delta$ & & $-7.34(-14.82,0.14)$ & 100.00 & & \\
\hline-300 & -200 & -100 & 100 & 200 & & & \\
\hline
\end{tabular}

Fig. 5. Mean difference in individual studies and summary WMD of zinc levels $(\mu \mathrm{g} / \mathrm{L})$ in serum/plasma and in CSF in patients with PD compared with controls. WMD, weighted mean difference; CSF, cerebrospinal fluid.

trations (Fig. 4). Some asymmetry in funnel plot suggested some publication bias in favor of lower trace element levels in patients for studies based on CSF, while there was little indication of such bias for studies on serum/plasma iron levels (online suppl. Fig. S1). Average iron concentrations did not differ between PD patients and controls across most studies, with the exception of 4 studies for CSF levels $[21,27,42,43]$ and 2 for serum/plasma mean concentrations $[44,45]$.

\section{Zinc}

In the 24 studies investigating this trace element, average zinc levels were lower in PD cases than in controls, both in CSF $(-10.8 \%$; WMD $-7.34,95 \%$ CI: -14.82 to $0.14)$ and serum/plasma (-7.5\%; WMD $-79.93,95 \%$ CI -143.80 to -16.06$)$, as shown in Table 2 . No study investigated zinc levels in whole blood. The heterogeneity of results was $95.1 \%$ in studies examining CSF levels and 98.1\% for those based on plasma/serum concentrations (Fig. 5). By repeating the analysis restricted to patients with shorter duration PD in 1 study [41], results did not change substantially (online suppl. Fig. S4). Some evidence of publication bias in favor of lower levels in PD patients emerged for both serum/plasma and CSF matrices (online suppl. Fig. S1).

\section{Sensitivity Analyses}

Some studies allowed to compare trace element levels in patients with recent PD diagnosis compared with those with longer disease duration (Table 3 and Fig. 6). Gellein et al. [46] detected higher serum trace element levels in 19 PD subjects sampled few months to few years before PD diagnosis, compared with values detected in the same patients several years (4-12 years) after disease diagnosis, 
Table 3. Studies comparing trace element levels in patients with PD with shorter and longer disease duration

\begin{tabular}{lllcc}
\hline Study & Matrix & Element & $\begin{array}{c}\text { Shorter duration } \\
\text { mean } \pm \mathrm{SD}, \mu \mathrm{g} / \mathrm{L}\end{array}$ & $\begin{array}{c}\text { Longer duration } \\
\text { mean } \pm \text { SD, } \mu \mathrm{g} / \mathrm{L}\end{array}$ \\
\hline Arnal et al. [19], 2010 & Plasma & Copper & $870 \pm 20$ & $1,020 \pm 40$ \\
Bharucha et al. [20], 2008 & Serum & Copper & $995 \pm 278$ & $1,044 \pm 272$ \\
Boll et al. [40], 1999 & CSF & Copper & $5.04 \pm 3.89$ & $4.21 \pm 3.12$ \\
Gellein et al. [46], 2008 & Serum & Selenium & $109.8 \pm 16.9$ & $73.0 \pm 18.3$ \\
& & Copper & $1,152 \pm 282$ & $1,116 \pm 258$ \\
& & Iron & $1,130 \pm 428$ & $949 \pm 325$ \\
& & Zinc & $1,026 \pm 323$ & $964 \pm 360$ \\
Hegde et al. [41], 2004 & Serum & Copper & $1,398 \pm 508.4$ & $1,271 \pm 381.3$ \\
& & Iron & $1,117 \pm 223.3$ & $949.4 \pm 390.9$ \\
Takahashi et al. [24], 1994 & Serum & Zinc & $523.0 \pm 130.8$ & $457.7 \pm 65.4$ \\
& CSF & Copper & $150 \pm 70$ & $120 \pm 20$ \\
& Serum & Copper & $1,390 \pm 33$ & $24 \pm 5$ \\
& CSF & Iron & $140 \pm 150$ & $1,090 \pm 600$ \\
& Serum & Iron & $1,690 \pm 610$ & $100 \pm 40$ \\
& CSF & Zinc & $280 \pm 200$ & $2,030 \pm 1,050$ \\
& Serum & Zinc & $1,880 \pm 760$ & $210 \pm 140$ \\
& & & $1,700 \pm 690$ \\
\hline
\end{tabular}

PD, Parkinson's disease; CSF, cerebrospinal fluid.

particularly for selenium and to a lesser extent for iron, copper, and zinc. Two of the 5 studies that analyzed copper serum levels in patients with different PD clinical duration found higher levels in patients with longer disease duration $[19,20]$, while 2 other studies found lower concentrations in this subgroup [24, 40, 41]. Takahashi et al. [24] compared trace element concentrations in PD patients with recent $\mathrm{PD}$ diagnosis (disease duration $2.0 \pm 1.3$ years) with those detected in patients with longer disease duration $(6.0 \pm 4.6$ years $)$, finding lower levels of selenium, copper, and zinc in patients with longer PD clinical course, while iron serum concentrations were higher. Hegde et al. [41] found lower levels of iron and zinc in patients with long-term illness, both in serum/plasma and CSF.

\section{Discussion}

In this systematic review and meta-analysis, we summarized the results of case-control studies comparing levels of selenium, copper, iron and zinc in patients with PD and controls in different biological matrices. To the best of our knowledge, this is the first meta-analysis assessing biomarkers of selenium levels and PD. We found similar selenium exposure in the serum or plasma of PD patients compared with controls, while CSF levels were consider- ably higher in PD patients. Such increased CSF selenium contents may either suggest that selenium overexposure in the central nervous system plays a role in disease etiology or indicate the occurrence of selective derangements of the trace element status as a consequence of disease onset and progression. The possible causal association between increased selenium exposure and PD risk is also supported by recent epidemiological findings showing an excess PD mortality in individuals exposed to selenium in its inorganic hexavalent form through drinking water [47]. Although conflicting evidence has been reported by nonhuman studies on the involvement of selenium in PD etiology [48], there is biological plausibility for such association. Selenium is a nutritionally essential element in the human owing to several properties such as its antioxidant activity, regulation of $\mathrm{Ca}^{2+}$ channels, and modulation of neurogenesis [49]. Nevertheless, selenium may also exert many adverse effects on several body systems including the central nervous system, encompassing the induction of oxidative stress and other mechanisms [50-54]. In particular, selenium might adversely affect dopaminergic neurons, since selenium overexposure may lead to neurodegeneration through the generation of reactive oxygen species and the alteration of mRNA expression of dopamine receptors, tyrosine hydroxylase, and dopamine transporter genes [55-59]. Selenium neurotoxicity may occur even at very low levels $[60,61]$, and it has been 

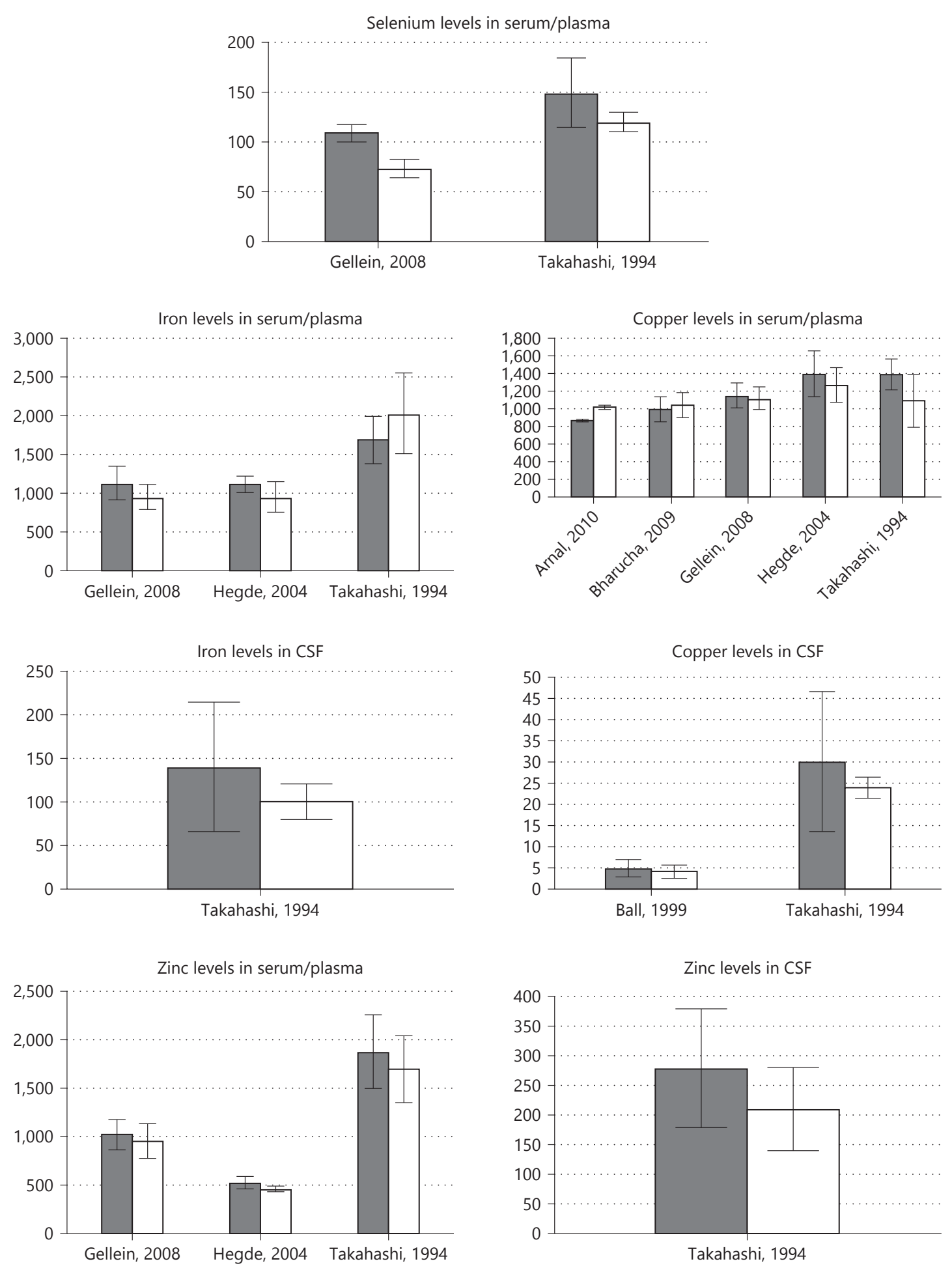

Fig. 6. Comparison of trace element levels $(\mu \mathrm{g} / \mathrm{L})$ in serum/plasma and CSF according to PD duration. Dark gray box: shorter PD duration, light gray box: longer PD duration, whiskers: SD. CSF, cerebrospinal fluid. 
shown that this element activates the p38 pathway [62], a mechanism implicated in PD etiopathogenesis [63].

Concerning copper and iron, we updated previous reviews by adding 9 and 18 studies, respectively $[64,65]$. Differently from previous reviews that could not identify appreciable differences between element levels in PD cases and controls, we found higher CSF levels in PD cases, while levels were lower in serum, plasma, and whole blood. A potential relevance of both copper and iron elements in $\mathrm{PD}$ etiopathogenesis has been reported by many investigators, including neurotoxic effects that may occur through different mechanisms [66-68]. Dusek et al. [69] suggested that iron metabolism dysregulation in substantia nigra is related to neurodegeneration. More recently, a synergistic mechanism between copper and iron has been suggested, with evidence for an interaction of these elements with a-synuclein [11, 70-73]. Copper and iron, such as other redox active metals, may also affect protein aggregation through the generation of free oxygen radicals $[74,75]$. In addition, impaired distribution of iron may lead to brain damage, and excess iron in the brain is a hallmark of neurodegenerative disorders such as Alzheimer's disease and amyotrophic lateral sclerosis [76-79].

In PD patients, selenium, copper, and iron all showed higher levels in CSF, but lower ones in serum/plasma or whole blood compared with controls. Such different findings for the same elements were not entirely unexpected. In fact, it has been shown that CSF trace element levels and their corresponding peripheral, circulating levels may not correlate, particularly in subjects with PD and other neurodegenerative diseases often related to impaired nutritional status [80-82]. In particular, alteration of metal transporters and/or alterations in blood-brain barrier may occur in these patients, affecting the CSF/ blood ratio of trace elements [83-85]. Lack of correlation between CSF and blood trace element levels may also stem from peculiarities in CNS detoxification system [86]. For selenium, some of its species, namely the inorganic ones, did not correlate between blood and CSF in healthy subjects, differently from the organic chemical forms $[87,88]$.

In terms of biological relevance and etiologic significance, we consider CSF trace element levels of higher importance than the blood ones. CSF is a biological matrix secreted by the central nervous system and forms an integral part of it, thus becoming highly relevant to the diagnosis of neurodegenerative diseases [89-91] including PD [92]. CSF is directly connected, without a barrier, to the extracellular space of brain parenchyma and facilitates molecular exchange. The composition of CSF and extracellular brain fluids is similar, and a misbalance or exposure and depletion of elements in the brain are reflected by CSF [93]. The importance of element levels in CSF as a biomarker of central nervous system exposure, compared with indicators in peripheral matrices such as serum/plasma or whole blood, is widely appreciated, also reflecting metabolic processes underlying brain parenchyma functioning $[87,94]$. Therefore, under an etiologic perspective, the increased trace element contents in the CSF of PD patients compared with controls are more important than the opposite findings for serum/plasma levels of these trace elements. In fact, the exposure within the central nervous system may be considered most relevant to PD (or more generally to neurodegenerative diseases) etiology, compared with peripheral exposure. This is particularly true for selenium, which showed by far the highest percent increase in CSF levels compared with the other trace elements tested. Conversely, no change in blood levels was detected, emphasizing how poorly this biomarker may mirror central nervous system exposure.

When assessing average trace element levels according to PD clinical duration, we generally observed lower levels in patients with longer-term illness, suggesting that $\mathrm{PD}$ progression is associated with a reduction of circulating trace element levels. This means that the higher CSF levels of these elements, and particularly of selenium, that we found in our meta-analysis are more likely to be involved in the causal pathway of the disease than to be an effect of disease itself. Alternatively, higher CSF levels may simply predict or accompany disease onset. Conversely, the low trace element levels detected in overall PD patients or in those selectively having a long clinical course are likely to be a consequence of disease itself, due to either an impaired nutritional status [80-82] or an alteration of trace element metabolism due to disease progression. Some studies assessed trace elements intake through diet in relation with PD risk, yielding inconsistent results though with some indication of a positive association with iron intake $[95,96]$. It is also possible that the increased CSF selenium contents may be a consequence of the increased synthesis of selenoproteins, enzymes with antioxidant properties, in the central nervous system, as a compensatory response to increased reactive oxygen species production [97]. This might also lead to a concomitant reduction in blood selenium contents. However, a better understanding of the mechanisms underpinning selenium changes in the central nervous system before and during PD is hampered by lack of data on changes of CSF selenium content according to disease duration. Overall, the findings for the other elements in both
18

Neuroepidemiology 2020;54:1-23 DOI: $10.1159 / 000502357$
Adani/Filippini/Michalke/Vinceti 
CSF and blood, and for selenium in blood, appear to confirm an etiologic role of high exposure to selenium, though less strongly to iron and copper, in PD etiology.

Based on 24 studies (a double number of the previous meta-analysis), we found lower zinc concentrations in both CSF and blood of PD patients, consistently with a possible role of zinc deficiency in disease etiopathogenesis. Our findings mirror those of a recent meta-analysis that evaluated the association between zinc serum levels and PD [98]. These results are of interest in light of role of zinc as an antioxidant enzyme cofactor, the increased oxidative stress following decreased zinc levels [99-102], and finally the observation that zinc supplements may improve PD severity in animal models [103]. Recent studies have underlined the key role of dysregulation of zinc concentration and its synergic interaction with dopaminergic system in both cells and animal models [104, 105]. However, the observation that zinc levels inversely correlated with PD duration in the few studies assessing such association raises the possibility of reverse causation, that is, of an effect of disease itself in decreasing zinc status. This suggests caution in hypothesizing that zinc deficiency may be a risk factor, and not a consequence, of PD.

We must acknowledge some limitations in the reviewed studies and in the results of this meta-analysis. First, particularly for some elements and matrices, the number of studies and their size were too low to yield a satisfactory statistical precision of the summary effect estimates, as shown by their wide confidence intervals. In addition, in several studies some relevant details of study population were lacking, such as PD duration and clinical severity in patients. Moreover, all studies we retrieved were case-control, a study design that may induce spurious associations from an etiological point of view. In fact, reverse causation is a key issue in assessing the etiological role of trace elements, as recently shown for selenium in Alzheimer's dementia by comparing the case-control with the longitudinal study design [106]. A further limitation also was that some reviewed studies included a control population who might not have been completely appropriate. In fact, they had undergone sample analysis because of some neurological symptoms, in turn possible related to trace element alterations and to potential selection bias. As previously mentioned, finally, no speciation analysis was available in the studies reviewed. This is a major limitation in light of what we know from the few available speciation studies on central nervous system disease, showing the relevance of the chemical forms of elements such as selenium or iron, and how speciation analysis may lead to entirely different results in the same study $[89,91,107]$. Nowadays, elemental speciation fosters important links between powerful techniques, from analytical chemistry to neurodevelopment or brain degeneration research [50]. Element speciation analysis has matured to provide key knowledge by investigating changes in both species concentration and the pattern of essential elements (e.g., SELENOP vs. Se [IV]) [89], or shifts in their redox pairs (e.g., Fe [II] vs. Fe [III] [108]). As such, it would definitively allow for deeper insights into the molecular mechanisms and pathways of PD. It would therefore be of fundamental importance to confirm and expand the scope of our study, by performing elemental speciation analysis for selenium as well as the other trace elements $[89,108]$.

In conclusion, our meta-analysis indicates that, despite their lower peripheral circulating trace element levels, PD patients exhibit higher levels of copper, iron, and particularly selenium in CSF compared with referents. Such higher exposure might be a risk factor of $\mathrm{PD}$, rather than a consequence of the disease, consistent with the biological plausibility of these associations. This seems to be particularly true for selenium, given some recent epidemiological and toxicological evidence on how its species may adversely affect dopamine metabolism. The decreased zinc levels found in PD patients also deserve careful scrutiny, since it might indicate a role of zinc deficiency in disease etiology, though we could not entirely rule out the possibility of reverse causation about this finding.

\section{Acknowledgments}

We are very grateful for Maass and coworkers and Bilen and coworkers for providing additional data useful for our review.

\section{Statements of Ethics}

The authors have no ethical conflicts to disclose.

\section{Disclosure Statement}

The authors have no conflicts of interest to declare.

\section{Author Contributions}

G.A., T.F., and M.V.: designed the study, G.A. and T.F.: performed literature search, data extraction, and data analysis. All authors (G.A., T.F., B.M., M.V.) contributed to the preparation of the draft, reviewed the manuscript, and approved its final form. 


\section{References}

1 Kouli A, Torsney KM, Kuan WL. Parkinson's Disease: Etiology, Neuropathology, and Pathogenesis. Parkinson's Disease: Pathogenesis and Clinical Aspects, 2018. chapter 1.

2 Dorsey ER, et al. Global, regional, and national burden of Parkinson's disease, 1990-2013; 2016: a systematic analysis for the Global Burden of Disease Study 2016. Lancet Neurol. 2018 Nov;17(11):939-53.

3 Lee A, Gilbert RM. Epidemiology of Parkinson Disease. Neurol Clin. 2016 Nov;34(4): 955-65.

4 Delamarre A, Meissner WG. Epidemiology, environmental risk factors and genetics of Parkinson's disease. Presse Med. 2017 Mar; 46(2 Pt 1):175-81.

5 Tysnes OB, Storstein A. Epidemiology of Parkinson's disease. J Neural Transm (Vienna). 2017 Aug;124(8):901-5.

6 Kalia LV, Lang AE. Parkinson's disease. Lancet. 2015 Aug;386(9996):896-912.

7 Abbas MM, Xu Z, Tan LC. Epidemiology of Parkinson's Disease-East Versus West. Mov Disord Clin Pract (Hoboken). 2017 Dec;5(1) 14-28.

8 Ritz B, Lee PC, Lassen CF, Arah OA. Parkinson disease and smoking revisited: ease of quitting is an early sign of the disease. Neurology. 2014 Oct;83(16):1396-402.

9 Lee PC, Ahmed I, Loriot MA, Mulot C, Paul KC, Bronstein JM, et al. Smoking and Parkinson disease: evidence for gene-by-smoking interactions. Neurology. 2018 Feb;90(7): e583-92.

10 Giacoppo S, Galuppo M, Calabrò RS, D’Aleo G, Marra A, Sessa E, et al. Heavy metals and neurodegenerative diseases: an observational study. Biol Trace Elem Res. 2014 Nov;161(2): 151-60.

11 Bjorklund G, Stejskal V, Urbina MA, Dadar M, Chirumbolo S, Mutter J. Metals and Parkinson's Disease: Mechanisms and Biochemical Processes. Curr Med Chem. 2018;25(19): 2198-214.

12 Vinceti M, Filippini T, Wise LA. Environmental Selenium and Human Health: an Update. Curr Environ Health Rep. 2018 Dec; 5(4):464-85.

13 Goetz CG, Poewe W, Rascol O, Sampaio C, Stebbins GT, Counsell C, et al.; Movement Disorder Society Task Force on Rating Scales for Parkinson's Disease. Movement Disorder Society Task Force report on the Hoehn and Yahr staging scale: status and recommendations. Mov Disord. 2004 Sep;19(9):1020-8.

14 Alimonti A, Bocca B, Pino A, Ruggieri F, Forte G, Sancesario G. Elemental profile of cerebrospinal fluid in patients with Parkinson's disease. J Trace Elem Med Biol. 2007;21(4): 234-41.

15 Casjens S, Dydak U, Dharmadhikari S, Lotz A, Lehnert M, Quetscher C, et al. Association of exposure to manganese and iron with striatal and thalamic GABA and other neurometabolites - Neuroimaging results from the
WELDOX II study. Neurotoxicology. 2018 Jan;64:60-7.

16 McIntosh KG, Cusack MJ, Vershinin A, Chen ZW, Zimmerman EA, Molho ES, et al. Evaluation of a prototype point-of-care instrument based on monochromatic x-ray fluorescence spectrometry: potential for monitoring trace element status of subjects with neurodegenerative disease. J Toxicol Environ Health A. 2012;75(21):1253-68.

17 Medeiros, MS, Schumacher-Schuh A, Cardoso AM, Bochi GV, Baldissarelli J, Kegler A, et al. Iron and Oxidative Stress in Parkinson's Disease: An Observational Study of Injury Biomarkers. PLoS One. 2016 Jan;11(1):e0146129.

18 Higgins JPT, S Green. Cochrane Handbook for Systematic Reviews of Interventions Version 5.1.0 [updated March 2011]. The Cochrane Collaboration, 2011.

19 Arnal N, Cristalli DO, de Alaniz MJ, Marra CA. Clinical utility of copper, ceruloplasmin, and metallothionein plasma determinations in human neurodegenerative patients and their first-degree relatives. Brain Res. 2010 Mar;1319:118-30.

20 Bharucha KJ, Friedman JK, Vincent AS, Ross ED. Lower serum ceruloplasmin levels correlate with younger age of onset in Parkinson's disease. J Neurol. 2008 Dec;255(12):1957-62.

$21 \mathrm{Hu}$ Y, Yu SY, Zuo LJ, Piao YS, Cao CJ, Wang $\mathrm{F}$, et al. Investigation on Abnormal Iron Metabolism and Related Inflammation in Parkinson Disease Patients with Probable RBD. PLoS One. 2015 Oct;10(10):e0138997.

22 Qureshi GA, Qureshi AA, Memon SA, Parvez $\mathrm{SH}$. Impact of selenium, iron, copper and zinc in on/off Parkinson's patients on L-dopa therapy. J Neural Transm Suppl. 2006;71:229-36.

23 Maass F, Michalke B, Leha A, Boerger M, Zerr I, Koch JC, et al. Elemental fingerprint as a cerebrospinal fluid biomarker for the diagnosis of Parkinson's disease. J Neurochem. 2018 May; 145(4):342-51.

24 Takahashi S, Takahashi J, Osawa N, Abe T, Yonezawa H, Sera K, et al. [Trace elements analysis of serum and cerebrospinal fluid with PIXE - effect of age and changes in parkinsonian patients]. Nippon Ronen Igakkai Zasshi. 1994 Nov;31(11):865-71.

25 Ahmed SS, Santosh W. Metallomic profiling and linkage map analysis of early Parkinson's disease: a new insight to aluminum marker for the possible diagnosis. PLoS One. 2010 Jun;5(6):e11252.

26 Farhoudi M, Taheraghdam A, Farid GA, Talebi M, Pashapou A, Majidi J, et al. Serum iron and ferritin level in idiopathic Parkinson. Pak J Biol Sci. 2012 Nov;15(22):1094-7.

27 Lian TH, Guo P, Zuo LJ, Hu Y, Yu SY, Yu QJ, et al. Tremor-Dominant in Parkinson Disease: The Relevance to Iron Metabolism and Inflammation. Front Neurosci. 2019 Mar; 13(255):255.

28 Alimonti A, Ristori G, Giubilei F, Stazi MA, Pino A, Visconti A, et al. Serum chemical ele- ments and oxidative status in Alzheimer's disease, Parkinson disease and multiple sclerosis. Neurotoxicology. 2007 May;28(3):450-6.

29 Forte G, Alimonti A, Pino A, Stanzione P, Brescianini S, Brusa L, et al. Metals and oxidative stress in patients with Parkinson's disease. Ann Ist Super Sanita. 2005;41(2):189-95.

30 Forte G, Alimonti A, Violante N, Di Gregorio M, Senofonte O, Petrucci F, et al. Calcium, copper, iron, magnesium, silicon and zinc content of hair in Parkinson's disease. J Trace Elem Med Biol. 2005;19(2-3):195-201.

31 Forte G, Bocca B, Senofonte O, Petrucci F, Brusa L, Stanzione P, et al. Trace and major elements in whole blood, serum, cerebrospinal fluid and urine of patients with Parkinson's disease. J Neural Transm (Vienna). 2004 Aug;111(8):1031-40.

32 Fukushima T, Tan X, Luo Y, Kanda H. Serum vitamins and heavy metals in blood and urine, and the correlations among them in Parkinson's disease patients in China. Neuroepidemiology. 2011;36(4):240-4.

33 Ilyechova EY, Miliukhina IV, Orlov IA, Muruzheva ZM, Puchkova LV, Karpenko MN. A low blood copper concentration is a co-morbidity burden factor in Parkinson's disease development. Neurosci Res. 2018 Oct; 135:54-62.

34 Jiménez-Jiménez FJ, Fernández-Calle P, Martínez-Vanaclocha M, Herrero E, Molina JA, Vázquez A, et al. Serum levels of zinc and copper in patients with Parkinson's disease. J Neurol Sci. 1992 Oct;112(1-2):30-3.

35 Marder K, Logroscino G, Tang MX, Graziano J, Cote L, Louis E, et al. Systemic iron metabolism and mortality from Parkinson's disease. Neurology. 1998 Apr;50(4):1138-40.

36 Molina-Arjona JA, de Bustos F, Benito-León J, Jiménez-Jiménez FJ, Rodríguez J, Trincado $\mathrm{R}$, et al. [Serum pro-oxidant and antioxidant factors and risk of Parkinson's disease: population study]. Rev Neurol. 1999 Jul;29(1):125.

37 Kanabrocki EL, Case LF, Graham L, Fields T, Miller EB, Oester YT, et al. Non-dialyzable manganese and copper levels in serum of patients with various diseases. J Nucl Med. 1967 Mar;8(3):166-72.

38 Aguilar MV, Jiménez-Jiménez FJ, Molina JA, Meseguer I, Mateos-Vega CJ, González-Muñoz MJ, et al. Cerebrospinal fluid selenium and chromium levels in patients with Parkinson's disease. J Neural Transm (Vienna). 1998;105(10-12):1245-51.

39 Jiménez-Jiménez FJ, Molina JA, Arrieta FJ, Aguilar MV, Cabrera-Valdivia F, Vázquez A, et al. Decreased serum selenium concentrations in patients with Parkinson's disease. Eur J Neurol. 1995 Apr;2(2):111-4.

40 Boll MC, Sotelo J, Otero E, Alcaraz-Zubeldia M, Rios C. Reduced ferroxidase activity in the cerebrospinal fluid from patients with Parkinson's disease. Neurosci Lett. 1999 Apr; 265(3):155-8. 
41 Hegde ML, Shanmugavelu P, Vengamma B, Rao TS, Menon RB, Rao RV, et al. Serum trace element levels and the complexity of inter-element relations in patients with Parkinson's disease. J Trace Elem Med Biol. 2004;18(2): $163-71$.

42 Pall HS, Williams AC, Blake DR, Lunec J, Gutteridge JM, Hall M, et al. Raised cerebrospinal-fluid copper concentration in Parkinson's disease. Lancet. 1987 Aug;2(8553):23841.

43 Willkommen D, Lucio M, Schmitt-Kopplin P, Gazzaz M, Schroeter M, Sigaroudi A, et al. Species fractionation in a case-control study concerning Parkinson's disease: $\mathrm{cu}$-amino acids discriminate CSF of PD from controls. J Trace Elem Med Biol. 2018 Sep;49:164-70.

44 Logroscino G, Marder K, Graziano J, Freyer G, Slavkovich V, LoIacono N, et al. Altered systemic iron metabolism in Parkinson's disease. Neurology. 1997 Sep;49(3):714-7.

45 Mariani S, Ventriglia M, Simonelli I, Bucossi S, Siotto M, Donno S, et al. Association between sex, systemic iron variation and probability of Parkinson's disease. Int J Neurosci. 2016;126(4):354-60.

46 Gellein K, Syversen T, Steinnes E, Nilsen TI, Dahl OP, Mitrovic S, et al. Trace elements in serum from patients with Parkinson's disease-a prospective case-control study: the Nord-Trøndelag Health Study (HUNT). Brain Res. 2008 Jul;1219:111-5.

47 Vinceti M, Ballotari P, Steinmaus C, Malagoli C, Luberto F, Malavolti M, et al. Long-term mortality patterns in a residential cohort exposed to inorganic selenium in drinking water. Environ Res. 2016 Oct;150:348-56.

48 Ellwanger JH, Molz P, Dallemole DR, Pereira dos Santos A, Müller TE, Cappelletti L, et al. Selenium reduces bradykinesia and DNA damage in a rat model of Parkinson's disease. Nutrition. 2015 Feb;31(2):359-65.

49 Cardoso BR, Roberts BR, Bush AI, Hare DJ. Selenium, selenoproteins and neurodegenerative diseases. Metallomics. 2015 Aug;7(8): 1213-28.

50 Vinceti M, Mandrioli J, Borella P, Michalke B, Tsatsakis A, Finkelstein Y. Selenium neurotoxicity in humans: bridging laboratory and epidemiologic studies. Toxicol Lett. 2014 Oct; 230(2):295-303.

51 Filippini T, et al. Selenium Neurotoxicity and Amyotrophic Lateral Sclerosis: An Epidemiologic Perspective. In: Michalke B, editor. Selenium. Molecular and Integrative Toxicology. Cham: Springer; 2018. https://doi. org/10.1007/978-3-319-95390-8_12.

52 de Andrade RB, Gemelli T, Guerra RB, Dani C, Wannmacher CM, Gomez R, et al. Acute exposure to the vinyl chalcogenide 3-methyl1-phenyl-2-(phenylseleno)oct-2-en-1-one induces oxidative stress in different brain area of rats. Cell Biochem Funct. 2014 Jul;32(5): $438-44$.

53 Medeiros MC, Mello A, Gemelli T, Teixeira C, de Almeida M, de Andrade RB, et al. Effect of chronic administration of the vinyl chalco- genide 3-methyl-1-phenyl-2-(phenylseleno) oct-2-en-1-one on oxidative stress in different brain areas of rats. Neurochem Res. 2012 May;37(5):928-34.

54 Zia S, Islam F. Selenium altered the levels of lipids, lipid peroxidation, and sulfhydryl groups in straitum and thalamus of rat. Biol Trace Elem Res. 2000 Dec;77(3):251-9.

55 Naderi M, Salahinejad A, Ferrari MC, Niyogi S, Chivers DP. Dopaminergic dysregulation and impaired associative learning behavior in zebrafish during chronic dietary exposure to selenium. Environ Pollut. 2018 Jun;237:17485.

56 Morgan, KL, Estevez AO, Mueller CL, CachoValadez B, Miranda-Vizuete A, Szewczyk NJ, et al., The glutaredoxin GLRX-21 functions to prevent selenium-induced oxidative stress in Caenorhabditis elegans. Toxicol Sci. 2010 Dec;118(2):530-43.

57 Rasekh HR, Davis MD, Cooke LW, Mazzio EA, Reams RR, Soliman KF. The effect of selenium on the central dopaminergic system: a microdialysis study. Life Sci. 1997;61(11): 1029-35.

58 Tsunoda M, Johnson VJ, Sharma RP. Increase in dopamine metabolites in murine striatum after oral exposure to inorganic but not organic form of selenium. Arch Environ Contam Toxicol. 2000 Jul;39(1):32-7.

59 Thomas JK, Janz DM. Dietary selenomethionine exposure in adult zebrafish alters swimming performance, energetics and the physiological stress response. Aquat Toxicol. 2011 Mar;102(1-2):79-86.

60 Burden CM, Elmore C, Hladun KR, Trumble JT, Smith BH. Acute exposure to selenium disrupts associative conditioning and longterm memory recall in honey bees (Apis mellifera). Ecotoxicol Environ Saf. 2016 May;127: 71-9.

61 Ayaz M, Dalkilic N, Tuncer S, Bariskaner H. Selenium-induced changes on rat sciatic nerve fibers: compound action potentials. Methods Find Exp Clin Pharmacol. 2008 May;30(4):271-5.

62 Rudolf E, Rudolf K, Červinka M. Selenium activates $\mathrm{p} 53$ and $\mathrm{p} 38$ pathways and induces caspase-independent cell death in cervical cancer cells. Cell Biol Toxicol. 2008 Apr;24(2):12341.

63 Karunakaran S, Ravindranath V. Activation of p38 MAPK in the substantia nigra leads to nuclear translocation of NF-kappaB in MPTP-treated mice: implication in Parkinson's disease. J Neurochem. 2009 Jun;109(6): 1791-9.

64 Cicero CE, Mostile G, Vasta R, Rapisarda V, Signorelli SS, Ferrante M, et al. Metals and neurodegenerative diseases. A systematic review. Environ Res. 2017 Nov; 159:82-94.

65 Mostile G, Cicero CE, Giuliano L, Zappia M, Nicoletti A. Iron and Parkinson's disease: A systematic review and meta-analysis. Mol Med Rep. 2017 May;15(5):3383-9.

66 Abbaoui A, Gamrani H. Neuronal, astroglial and locomotor injuries in subchronic copper intoxicated rats are repaired by curcumin: A possible link with Parkinson's disease. Acta Histochem. 2018 Aug;120(6):542-50.

67 Kaur D, Yantiri F, Rajagopalan S, Kumar J, Mo JQ, Boonplueang R, et al. Genetic or pharmacological iron chelation prevents MPTPinduced neurotoxicity in vivo: a novel therapy for Parkinson's disease. Neuron. 2003 Mar; 37(6):899-909.

68 Zhu W, Xie W, Pan T, Xu P, Fridkin M, Zheng $\mathrm{H}$, et al. Prevention and restoration of lactacystin-induced nigrostriatal dopamine neuron degeneration by novel brain-permeable iron chelators. FASEB J. 2007 Dec;21(14): 3835-44.

69 Dusek P, Roos PM, Litwin T, Schneider SA, Flaten TP, Aaseth J. The neurotoxicity of iron, copper and manganese in Parkinson's and Wilson's diseases. J Trace Elem Med Biol. 2015;31:193-203.

70 Binolfi A, Quintanar L, Bertoncini CW, Griesinger C, Fernandez CO. Bioinorganic chemistry of copper coordination to alphasynuclein: relevance to Parkinson's disease. Coord Chem Rev. 2012;256(19-20):21882201.

71 Carboni E, Lingor P. Insights on the interaction of alpha-synuclein and metals in the pathophysiology of Parkinson's disease. Metallomics. 2015 Mar;7(3):395-404.

72 Song N, Xie J. Iron, Dopamine, and a-Synuclein Interactions in at-Risk Dopaminergic Neurons in Parkinson's Disease. Neurosci Bull. 2018 Apr;34(2):382-4.

73 Bharathi, Rao KS. Molecular understanding of copper and iron interaction with $\alpha$-synuclein by fluorescence analysis. J Mol Neurosci. 2008 Jul;35(3):273-81.

74 Migliorini C, Porciatti E, Luczkowski M, Valensin D. Structural characterization of $\mathrm{Cu} 2+$, $\mathrm{Ni} 2+$ and $\mathrm{Zn} 2+$ binding sites of model peptides associated with neurodegenerative diseases. Coord Chem Rev. 2012;256(1-2):35268.

75 Cruces-Sande A, Rodríguez-Pérez AI, Herbello-Hermelo P, Bermejo-Barrera P, Méndez-Álvarez E, Labandeira-García JL, et al. Copper Increases Brain Oxidative Stress and Enhances the Ability of 6-Hydroxydopamine to Cause Dopaminergic Degeneration in a Rat Model of Parkinson's Disease. Mol Neurobiol. 2019 Apr;56(4):2845-54.

76 Kozlowski H, Luczkowski M, Remelli M, Valensin D. Copper, zinc and iron in neurodegenerative diseases (Alzheimer's, Parkinson's and prion diseases). Coord Chem Rev. 2012; 256(19-20):2129-41.

77 Ong WY, Farooqui AA. Iron, neuroinflammation, and Alzheimer's disease. J Alzheimers Dis. 2005 Nov;8(2):183-200.

78 Quintana C, Bellefqih S, Laval JY, GuerquinKern JL, Wu TD, Avila J, et al. Study of the localization of iron, ferritin, and hemosiderin in Alzheimer's disease hippocampus by analytical microscopy at the subcellular level. J Struct Biol. 2006 Jan;153(1): $42-54$. 
79 Salvador GA. Iron in neuronal function and dysfunction. Biofactors. 2010 Mar-Apr;36(2): 103-10.

80 Tomic S, Pekic V, Popijac Z, Pucic T, Petek M, Kuric TG, et al. What increases the risk of malnutrition in Parkinson's disease? J Neurol Sci. 2017 Apr;375:235-8.

81 Sheard JM, Ash S, Silburn PA, Kerr GK. Prevalence of malnutrition in Parkinson's disease: a systematic review. Nutr Rev. 2011 Sep;69(9): 520-32.

82 Tan AH, Hew YC, Lim SY, Ramli NM, Kamaruzzaman SB, Tan MP, et al. Altered body composition, sarcopenia, frailty, and their clinico-biological correlates, in Parkinson's disease. Parkinsonism Relat Disord. 2018 Nov;56:58-64.

83 Liu C, Liang MC, Soong TW. Nitric Oxide, Iron and Neurodegeneration. Front Neurosci. 2019 Feb;13:114-114.

84 Belaidi AA, Bush AI. Iron neurochemistry in Alzheimer's disease and Parkinson's disease:targets for therapeutics. J Neurochem. 2016 Oct;139 Suppl 1:179-97.

85 Garrick MD, Singleton ST, Vargas F, Kuo HC, Zhao L, Knöpfel M, et al. DMT1: which metals does it transport? Biol Res. 2006;39(1):79-85.

86 Hauser-Davis RA, Silva JA, Rocha RC, Saint'Pierre T, Ziolli RL, Arruda MA. Acute selenium selenite exposure effects on oxidative stress biomarkers and essential metals and trace-elements in the model organism zebrafish (Danio rerio). J Trace Elem Med Biol. 2016 Jan;33:68-72.

87 Solovyev N, Berthele A, Michalke B. Selenium speciation in paired serum and cerebrospinal fluid samples. Anal Bioanal Chem. 2013 Feb; 405(6):1875-84.

88 Michalke BS, Vinceti M. Se-speciation investigations at neural barrier (NB). 11th international Symposium on selenium in Biology and Medicine, Stockholm; 2017.

89 Vinceti M, Solovyev N, Mandrioli J, Crespi CM, Bonvicini F, Arcolin E, et al. Cerebrospinal fluid of newly diagnosed amyotrophic lateral sclerosis patients exhibits abnormal levels of selenium species including elevated selenite. Neurotoxicology. 2013 Sep;38:2532.

90 Mandrioli J, Michalke B, Solovyev N, Grill P, Violi F, Lunetta C, et al. Elevated Levels of Selenium Species in Cerebrospinal Fluid of Amyotrophic Lateral Sclerosis Patients with Disease-Associated Gene Mutations. Neurodegener Dis. 2017;17(4-5):171-80.

91 Vinceti M, Chiari A, Eichmüller M, Rothman KJ, Filippini T, Malagoli C, et al. A selenium species in cerebrospinal fluid predicts conversion to Alzheimer's dementia in persons with mild cognitive impairment. Alzheimers Res Ther. 2017 Dec;9(1):100-100.

92 Kang UJ, Boehme AK, Fairfoul G, Shahnawaz M, Ma TC, Hutten SJ, et al. Comparative study of cerebrospinal fluid $\alpha$-synuclein seeding aggregation assays for diagnosis of Parkinson's disease. Mov Disord. 2019 Apr; 34(4):536-44
93 Damkier HH, Brown PD, Praetorius J. Cerebrospinal fluid secretion by the choroid plexus. Physiol Rev. 2013 Oct;93(4):184792.

94 Johar I, Mollenhauer B, Aarsland D. Chapter Ten - Cerebrospinal Fluid Biomarkers of Cognitive Decline in Parkinson's Disease. In: Bhatia KP, Chaudhuri KR, Stamelou M, editors. International Review of Neurobiology. Academic Press; 2017. pp. 275-94.

95 Cheng P, Yu J, Huang W, Bai S, Zhu X, Qi Z, et al. Dietary intake of iron, zinc, copper, and risk of Parkinson's disease: a meta-analysis. Neurol Sci. 2015 Dec;36(12):2269-75.

96 Erro R, Brigo F, Tamburin S, Zamboni M, Antonini A, Tinazzi M. Nutritional habits, risk, and progression of Parkinson disease. J Neurol. 2018 Jan;265(1):12-23.

97 Hatfield DL, Tsuji PA, Carlson BA, Gladyshev VN. Selenium and selenocysteine: roles in cancer, health, and development. Trends Biochem Sci. 2014 Mar;39(3):112-20.

98 Sun H, Liu X, Ge H, Wang T, Wang Y, Li W. Association Between Serum Zinc Levels and the Risk of Parkinson's Disease: a MetaAnalysis. Biol Trace Elem Res. 2017 Sep; 179(1):45-51.

99 Forsleff L, Schauss AG, Bier ID, Stuart S. Evidence of functional zinc deficiency in Parkinson's disease. J Altern Complement Med. 1999 Feb;5(1):57-64.

100 Ooi TC, Mohammad NH, Sharif R. Zinc carnosine protects against hydrogen peroxideinduced DNA damage in WIL2-NS lymphoblastoid cell line independent of poly (ADPRibose) polymerase expression. Biol Trace Elem Res. 2014 Dec;162(1-3):8-17.

101 Kara E, Gunay M, Cicioglu I, Ozal M, Kilic M, Mogulkoc R, et al.; Effect of Zinc Supplementation on Antioxidant Activity in Young Wrestlers. Effect of zinc supplementation on antioxidant activity in young wrestlers. Biol Trace Elem Res. 2010 Apr;134(1):55-63.

102 Dhanasekaran M, Albano CB, Pellet L, Karuppagounder SS, Uthayathas S, Suppiramaniam $\mathrm{V}$, et al. Role of lipoamide dehydrogenase and metallothionein on 1-methyl4-phenyl-1,2,3,6- tetrahydropyridine-induced neurotoxicity. Neurochem Res. 2008 Jun;33(6):980-4.

103 Saini N, Schaffner W. Zinc supplement greatly improves the condition of parkin mutant Drosophila. Biol Chem. 2010 May;391(5): 513-8.

104 Tamano H, Nishio R, Morioka H, Takeda A. Extracellular Zn2+ Influx into Nigral Dopaminergic Neurons Plays a Key Role for Pathogenesis of 6-Hydroxydopamine-Induced Parkinson's Disease in Rats. Mol Neurobiol. 2019 Jan;56(1):435-43.

105 Yang TC, Wu PC, Chung IF, Jiang JH, Fann MJ, Kao LS. Cell death caused by the synergistic effects of zinc and dopamine is mediated by a stress sensor gene Gadd45b - implication in the pathogenesis of Parkinson's disease. J Neurochem. 2016 Oct;139(1):120 33.
106 Vinceti M, Michalke B, Malagoli C, Eichmüller M, Filippini T, Tondelli M, et al. Selenium and selenium species in the etiology of Alzheimer's dementia: the potential for bias of the case-control study design. J Trace Elem Med Biol. 2019 May;53:154-62.

107 Fernsebner K, Zorn J, Kanawati B, Walker A Michalke B. Manganese leads to an increase in markers of oxidative stress as well as to a shift in the ratio of $\mathrm{Fe}(\mathrm{II}) /(\mathrm{III})$ in rat brain tissue. Metallomics. 2014 Apr;6(4):921-31.

108 Solovyev N, Vinceti M, Grill P, Mandrioli J, Michalke B. Redox speciation of iron, manganese, and copper in cerebrospinal fluid by strong cation exchange chromatography sector field inductively coupled plasma mass spectrometry. Anal Chim Acta. 2017 Jun; 973:25-33.

109 Abbott RA, Cox M, Markus H, Tomkins A. Diet, body size and micronutrient status in Parkinson's disease. Eur J Clin Nutr. 1992 Dec;46(12):879-84.

110 Annanmaki T, Muuronen A, Murros K. Low plasma uric acid level in Parkinson's disease. Mov Disord. 2007 Jun;22(8):1133-7.

111 Baillet A, Chanteperdrix V, Trocmé C, Casez P, Garrel C, Besson G. The role of oxidative stress in amyotrophic lateral sclerosis and Parkinson's disease. Neurochem Res. 2010 Oct;35(10):1530-7.

112 Bocca B, Alimonti A, Senofonte O, Pino A, Violante N, Petrucci F, et al. Metal changes in CSF and peripheral compartments of parkinsonian patients. J Neurol Sci. 2006 Oct; 248(1-2):23-30

113 Boll MC, Alcaraz-Zubeldia M, Montes S, Rios C. Free copper, ferroxidase and SOD1 activities, lipid peroxidation and $\mathrm{NO}(\mathrm{x})$ content in the CSF. A different marker profile in four neurodegenerative diseases. Neurochem Res. 2008 Sep;33(9):1717-23.

114 Bolner A, Micciolo R, Bosello O, Nordera GP. A Panel of Oxidative Stress Markers in Parkinson's Disease. Clin Lab. 2016;62(1-2): $105-12$.

115 Brewer GJ, Kanzer SH, Zimmerman EA, Molho ES, Celmins DF, Heckman SM, et al. Subclinical zinc deficiency in Alzheimer's disease and Parkinson's disease. Am J Alzheimers Dis Other Demen. 2010 Nov;25(7): 572-5.

116 Cabrera-Valdivia F, Jiménez-Jiménez FJ, Molina JA, Férnandez-Calle P, Vázquez A, Cañizares-Liébana F, et al. Peripheral iron metabolism in patients with Parkinson's disease. J Neurol Sci. 1994 Aug;125(1):82-6.

117 Chen WH, Shih PY. The serum ferrokinetics in Parkinson's disease. Gaoxiong Yi Xue Ke Xue Za Zhi. 1992 Nov;8(11):581-4.

118 de Farias CC, Maes M, Bonifacio KL, Matsumoto AK, Bortolasci CC, Nogueira AS, et al. Parkinson's Disease is Accompanied by Intertwined Alterations in Iron Metabolism and Activated Immune-inflammatory and Oxidative Stress Pathways. CNS Neurol Disord Drug Targets. 2017;16(4):48491. 
119 Costa-Mallen P, Gatenby C, Friend S, Maravilla KR, Hu SC, Cain KC, et al. Brain iron concentrations in regions of interest and relation with serum iron levels in Parkinson disease. J Neurol Sci. 2017 Jul;378:38-44.

120 Costa-Mallen P, Zabetian CP, Agarwal P, Hu SC, Yearout D, Samii A, et al. Haptoglobin phenotype modifies serum iron levels and the effect of smoking on Parkinson disease risk. Parkinsonism Relat Disord. 2015 Sep;21(9):1087-92.

121 Deng Q, Zhou X, Chen J, Pan M, Gao H, Zhou J, et al. Lower hemoglobin levels in patients with parkinson's disease are associated with disease severity and iron metabolism. Brain Res. 2017 Jan;1655:145-51.

122 Stefano F, Cinzia N, Marco P, Marco G, Rita G, Augusto F, et al. Hair Microelement Profile as a Prognostic Tool in Parkinson's Disease. Toxics. 2016 Nov;4(4):E27.

123 Fukushima T, Tan X, Luo Y, Kanda H. Relationship between blood levels of heavy metals and Parkinson's disease in China. Neuroepidemiology. 2010;34(1):18-24.

124 Gangania MK, Batra J, Kushwaha S, Agarwal R. Role of Iron and Copper in the Pathogenesis of Parkinson's Disease. Indian J Clin Biochem. 2017 Jul;32(3):353-6.

125 Gazzaniga GC, Ferraro B, Camerlingo M, Casto L, Viscardi M, Mamoli A. A case control study of CSF copper, iron and manganese in Parkinson disease. Ital J Neurol Sci. 1992 Apr;13(3):239-43.

126 Hemmati-Dinarvand M, Taher-Aghdam AA, Mota A, Zununi Vahed S, Samadi N. Dysregulation of serum NADPH oxidase1 and ferritin levels provides insights into diagnosis of Parkinson's disease. Clin Biochem. 2017 Dec;50(18):1087-92.

127 Hozumi I, Hasegawa T, Honda A, Ozawa K, Hayashi Y, Hashimoto K, et al. Patterns of levels of biological metals in CSF differ among neurodegenerative diseases. J Neurol Sci. 2011 Apr;303(1-2):95-9.

128 Jiménez-Jiménez FJ, Molina JA, Aguilar MV, Meseguer I, Mateos-Vega CJ, GonzálezMuñoz MJ, et al. Cerebrospinal fluid levels of transition metals in patients with Parkin- son's disease. J Neural Transm (Vienna). 1998;105(4-5):497-505.

129 Karpenko MN, Ilyicheva EY, Muruzheva ZM, Milyukhina IV, Orlov YA, Puchkova LV. Role of Copper Dyshomeostasis in the Pathogenesis of Parkinson's Disease. Bull Exp Biol Med. 2018 Mar;164(5):596-600.

130 Kim MJ, Oh SB, Kim J, Kim K, Ryu HS, Kim MS, et al. Association of metals with the risk and clinical characteristics of Parkinson's disease. Parkinsonism Relat Disord. 2018 Oct;55:117-21.

131 Kocatürk PA, Akbostanci MC, Tan F, Kavas GO. Superoxide dismutase activity and zinc and copper concentrations in Parkinson's disease. Pathophysiology. 2000 Apr;7(1): 63-7.

132 Kumudini N, Uma A, Devi YP, Naushad SM, Mridula R, Borgohain R, et al. Association of Parkinson's disease with altered serum levels of lead and transition metals among South Indian subjects. Indian J Biochem Biophys. 2014 Apr;51(2):121-6.

133 Larumbe Ilundáin R, Ferrer Valls JV, Viñes Rueda JJ, Guerrero D, Fraile P. [Case-control study of markers of oxidative stress and metabolism of blood iron in Parkinson's disease]. Rev Esp Salud Publica. 2001 Jan-Feb; 75(1):43-53.

134 Madenci G, Bilen S, Arli B, Saka M, Ak F. Serum iron, vitamin B12 and folic acid levels in Parkinson's disease. Neurochem Res. 2012 Jul;37(7):1436-41.

135 Mischley LK, Allen J, Bradley R. Coenzyme Q10 deficiency in patients with Parkinson's disease. J Neurol Sci. 2012 Jul;318(1-2):72-5.

136 Nikam S, Nikam P, Ahaley SK, Sontakke AV. Oxidative stress in Parkinson's disease. Indian J Clin Biochem. 2009 Jan;24(1):98101.

137 Sanyal J, Ahmed SS, Ng HK, Naiya T, Ghosh E, Banerjee TK, et al. Metallomic Biomarkers in Cerebrospinal fluid and Serum in patients with Parkinson's disease in Indian population. Sci Rep. 2016 Oct;6(1):3509735097.

138 Schirinzi T, Martella G, D’Elia A, Di Lazzaro G, Imbriani P, Madeo G, et al. Outlining a
Population “at Risk” of Parkinson's Disease: Evidence from a Case-Control Study. Parkinsons Dis. 2016;2016:9646057.

139 Shahar A, Patel KV, Semba RD, Bandinelli S, Shahar DR, Ferrucci L, et al. Plasma selenium is positively related to performance in neurological tasks assessing coordination and motor speed. Mov Disord. 2010 Sep; 25(12):1909-15.

140 Squitti R, Gorgone G, Panetta V, Lucchini R, Bucossi S, Albini E, et al. Implications of metal exposure and liver function in Parkinsonian patients resident in the vicinities of ferroalloy plants. J Neural Transm (Vienna). 2009 Oct;116(10):1281-7.

141 Squitti R, Gorgone G, Binetti G, Ghidoni R, Pasqualetti P, Draicchio F, et al. [Metals and oxidative stress in Parkinson's disease from industrial areas with exposition to environmental toxins or metal pollution]. G Ital Med Lav Ergon. 2007 Jul-Sep;29(3 Suppl): 294-6.

142 Tórsdóttir G, Kristinsson J, Sveinbjörnsdóttir S, Snaedal J, Jóhannesson T. Copper, ceruloplasmin, superoxide dismutase and iron parameters in Parkinson's disease. Pharmacol Toxicol. 1999 Nov;85(5 s1):239-43.

143 Verma AK, Keshari AK, Raj J, Kumari R, Kumar T, Sharma V, et al. Prolidase-Associated Trace Elements ( $\mathrm{Mn}, \mathrm{Zn}, \mathrm{Co}$, and $\mathrm{Ni}$ ) in the Patients with Parkinson's Disease. Biol Trace Elem Res. 2016 May;171(1):48-53.

144 Xu W, Zhi Y, Yuan Y, Zhang B, Shen Y, Zhang $\mathrm{H}$, et al. Correlations between abnormal iron metabolism and non-motor symptoms in Parkinson's disease. J Neural Transm (Vienna). 2018 Jul;125(7):1027-32.

145 Younes-Mhenni S, Aissi M, Mokni N, Boughammoura-Bouatay A, Chebel S, FrihAyed M, et al. Serum copper, zinc and selenium levels in Tunisian patients with Parkinson's disease. Tunis Med. 2013 Jun; 91(6):402-5.

146 Zhao HW, Lin J, Wang XB, Cheng X, Wang JY, Hu BL, et al. Assessing plasma levels of selenium, copper, iron and zinc in patients of Parkinson's disease. PLoS One. 2013 Dec; 8(12):e83060 